\title{
Modeling climate change effects on runoff and soil erosion in southeastern Arizona rangelands and implications for mitigation with conservation practices
}

\author{
Y. Zhang, M. Hernandez, E. Anson, M.A. Nearing, H. Wei, J.J. Stone, and P. Heilman
}

\begin{abstract}
Climate change is expected to impact runoff and soil erosion on rangelands in the western United States. This study evaluated the potential impacts of precipitation changes on soil erosion and surface runoff in southeastern Arizona using seven General Circulation Model (GCM) models with three emission scenarios for the 2050s and 2090s. A spatialtemporal downscaling process was used to generate daily precipitation series from GCM outputs for runoff and erosion modeling with the Rangeland Hydrology and Erosion Model (RHEM). Results were compared to 1970 through 1999 conditions. Our results suggested no significant changes in annual precipitation across the region under the three emission scenarios, while projected mean annual runoff and soil loss increased significantly, ranging from $79 \%$ to $92 \%$ and from $127 \%$ to $157 \%$, respectively, relative to 1970 to 1999 . At the seasonal scale, though an increase of summer precipitation and a reduction of winter precipitation were projected, both runoff and soil loss increased significantly for both periods. The dramatic increases in runoff and soil loss were attributed to the increase in the frequency and intensity of extreme events in the study area. Predicted soil loss from shrub communities increased more than that predicted for other plant communities under the three emission scenarios. Future increases in runoff and soil erosion may accelerate the transitions of grassland to shrublands or to more eroded states due to the positive vegetation-erosion feedback. Rangeland management policies and practices should consider these changes and adapt to the increased risk of runoff and soil erosion.
\end{abstract}

Key words: climate change-General Circulation Model-management practices_-rangelands-Rangeland Hydrology and Erosion Model—soil erosion

\begin{abstract}
Climate changes related to temperature and precipitation patterns are occurring and are expected to affect surface runoff and soil erosion in many environments. In the Fourth Assessment Report, the Intergovernmental Panel on Climate Change (IPCC) concluded that human influence has contributed to the trend toward more extreme precipitation events and that future increases in extreme precipitation are very likely (IPCC 2007). These findings are consistent with previous studies of extreme precipitation patterns across the globe. Increases in extreme events of precipitation in many areas worldwide have been observed in the measured data records, and General Circulation Model (GCM) outputs also show
\end{abstract}

rangelands(Nearing et al. 2005), especially at the regional scale. Studies also have been conducted to investigate the response of several different soil erosion models to precipitation and cover with a sensitivity analysis (Nearing et al. 2005). They found that relative results from the models were better than absolute predictions, and soil erosion was more affected by changes in rainfall and cover than was runoff.

Rangelands comprise approximately $40 \%$ of the lands of the United States, including nearly $80 \%$ of the land area of the western states (Weltz et al. 2008). Rangelands are an important renewable resource and provide valuable products such as fiber, water, clean air, wildlife habitat, and grazing land for livestock. In the southwestern United States, rangelands are the dominant land type and have experienced more than a century of transition from grasslands to shrublands due to climate change, overgrazing, and fire control (Platt 1959; Cable and Martin 1973; McClaran 2003). This transition is thought to have increased runoff and soil loss by water erosion on rangelands (Martin and Morton 1993). Soil erosion is a primary cause of degradation on most semiarid rangelands. Management practices, including prescribed grazing, prescribed fire, and brush management, are usually implemented on rangelands to reduce losses of soil, nutrients, and other biological and chemical materials (Weltz et al. 2008).

In the southwestern United States, humaninduced climate change appears to already be underway. Annual precipitation over the southwestern United States has decreased, and warmer temperature trends have been observed (IPCC 2007; Karl et al. 2009). Recent studies also suggest that drought frequency and severity have increased in this region (Groisman et al. 2004; Ellis et al. 2010). With projections for future climate to continue to warm in the southwestern United are to be expected (Easterling et al. 2000).

Impacts of climate change, including changes in precipitation, temperature, and carbon dioxide $\left(\mathrm{CO}_{2}\right)$ concentration on runoff and soil erosion, have been evaluated by many studies using existing erosion models, such as the Water Erosion Prediction Project model (Flanagan and Nearing 1995), from GCM projections (Zhang et al. 2004; Zhang and Liu 2005; O'Neal et al. 2005). However, these studies mainly focused on cultivated croplands. Few studies have been made about climate change effects on surface runoff and soil erosion in arid and semiarid
Yongguang Zhang is an assistant research scientist at the USDA Agricultural Research Service Southwest Watershed Research Center, Tucson, Arizona, and at the Institute of Mountain Hazards and Environment, Chinese Academy of Sciences, Chengdu, China. Mariano Hernandez is a hydrologist, Eric Anson is a computer specialist, Mark A. Nearing is a research agricultural engineer, Haiyan Wei is an assistant research scientist, Jeff J. Stone is a research hydrologist, and Phil Heilman is research leader at the USDA Agricultural Research Service Southwest Watershed Research Center, Tucson, Arizona. 
Table 1

Mean canopy cover, litter cover, rock cover, and soil information for sample points across four plant communities in the MLRA 41.

\begin{tabular}{llllllllll}
\hline $\begin{array}{l}\text { Plant } \\
\text { community }\end{array}$ & $\begin{array}{l}\text { Number } \\
\text { of points }\end{array}$ & $\begin{array}{l}\text { Canopy } \\
\text { cover (\%) }\end{array}$ & $\begin{array}{l}\text { Ground } \\
\text { cover (\%) }\end{array}$ & $\begin{array}{l}\text { Litter } \\
\text { cover (\%) }\end{array}$ & $\begin{array}{l}\text { Rock } \\
\text { cover (\%) }\end{array}$ & $\begin{array}{l}\text { Sand } \\
\text { content (\%) }\end{array}$ & $\begin{array}{l}\text { Clay } \\
\text { content (\%) }\end{array}$ & $\begin{array}{l}\boldsymbol{k}_{\mathbf{e}} \\
\left(\mathbf{m m} \mathbf{h}^{-1}\right)\end{array}$ & $\boldsymbol{k}_{\text {ss }}$ \\
\hline BUG & 30 & $50.7(28.4)$ & $53.7(27.9)$ & $25.2(15.3)$ & $21.2(27.2)$ & $39.4(10.9)$ & $17.2(8.5)$ & $3.6(3.2)$ & $827.3(208.9)$ \\
SOG & 12 & $43.5(22.6)$ & $56.2(19.5)$ & $33.9(20.8)$ & $18.3(21.0)$ & $35.2(16.6)$ & $24.2(3.8)$ & $2.1(2.0)$ & $781.9(212.0)$ \\
AGF & 25 & $48.0(24.9)$ & $59.4(29.0)$ & $27.7(18.0)$ & $29.8(28.6)$ & $44.8(15.7)$ & $17.4(8.1)$ & $3.7(3.1)$ & $816.6(214.9)$ \\
SHR & 84 & $37.3(19.3)$ & $68.9(23.1)$ & $25.6(16.6)$ & $40.7(27.8)$ & $40.1(16.9)$ & $17.2(8.4)$ & $4.7(2.9)$ & $1,216.5(1,236.7)$ \\
\hline
\end{tabular}

Notes: $k_{\mathrm{e}}=$ hydraulic conductivity. $k_{\mathrm{ss}}$ (dimensionless) $=$ splash and sheet coefficient. Numbers in parentheses are the standard deviation of all sample points for each plant community.

States, the trend in this region will be toward a more arid climate and a significant drying during the 21st century (Seager et al. 2007, 2010). Also expected is an increased risk of flooding due to more variable precipitation with more extreme events (Goodrich and Ellis 2008; Karl et al. 2009). The frequency of extreme precipitation events for the upper 5 th percentile of daily rainfall amounts has been increasing in the southwestern United States since the 1930s (Easterling et al. 2000). Intense precipitation is projected to continue to increase in this region, especially during future El Niño events (IPCC 2007).

The potential impacts on runoff and soil erosion and the actual damages in southwestern United States rangelands need to be assessed under these projected climate changes. Further conservation implications relate to whether changes in management practices are warranted under climate change and what practices would need to be adapted to help mitigate the increased risk of surface runoff and soil erosion. Observations and measurements at the Santa Rita Experiment Range in the southern Arizona indicated that water erosion dominates over wind erosion (Zhang et al. 2011). Therefore, the focus herein is potential changes in soil erosion by water.

The objective of this study was to assess potential changes in runoff and erosion with respect to changes in precipitation patterns in southeastern Arizona rangelands for current vegetation conditions for the periods of 2030 through 2059 and 2070 through 2099 from multiple GCM and emission scenarios. The implications of these changes on mitigation through rangeland conservation practices were also addressed.

\section{Materials and Methods}

Study Area and Observed Data. The study area, Major Land Resources Area (MLRA) 41, is located in southeastern Arizona (89\%) and southwestern New Mexico (11\%) with a total area of 40,765 $\mathrm{km}^{2}\left(15,739 \mathrm{mi}^{2}\right)$ (figure 1) (USDA NRCS 2006). MLRA 41 is a very

\section{Figure 1}

The study area: Major Land Resource Area 41.

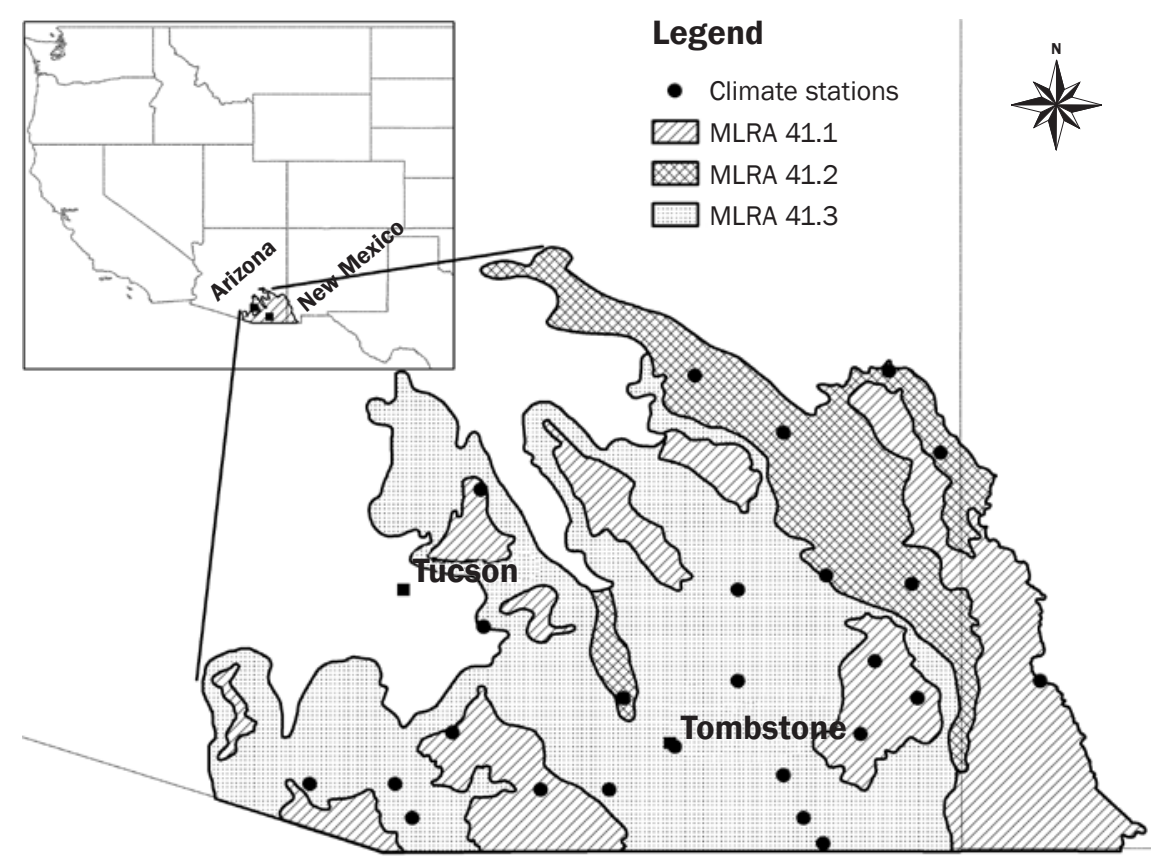

diverse ecological area located in the transition zone between the Sonoran and Chihuahuan Deserts, characterized by a distinctive pattern of topography, soil, climate, water resources, and land use. The geomorphology consists of a series of isolated mountain chains and intermountain basins with alluvial valleys. Elevation ranges from approximately 800 to $1,400 \mathrm{~m}(2,625$ to $4,593 \mathrm{ft})$ in the valleys and from 1,400 to $1,800 \mathrm{~m}(4,593$ to $5,906 \mathrm{ft})$ in the mountains. The average annual precipitation increases with elevation and ranges from 230 to over $600 \mathrm{~mm}$ (9 to over $24 \mathrm{in}$ ), of which more than half occurs as high intensity thunderstorms during the summer monsoon between early July and mid-September. December to March is the secondary rainy season. Soils in MLRA 41 are dominated by Aridisols, Entisols, Alfisols, and Mollisols
(USDA NRCS 2006). About one-third of the study area is federally owned, and most of the area is used for livestock grazing.

Measurements were made of vegetation, ground cover, and topography at 151 randomly distributed sites in MLRA 41 between 2003 and 2006 (table 1). Soil properties, including texture information, porosity, and bulk density, were extracted from the Natural Resources Conservation Service Soil Survey Geographic soil database (USDA NRCS 2012) for each of the 151 sample points (table 1). These data were used to build input files for the runoff and erosion modeling. The dominant plant growth habitats at the 151 points in MLRA 41were distributed as 30 bunch grass, 12 sod grass, 25 annual grass and forbs, and 84 shrub. 
Table 2

Summary of General Circulation Models (GCMs) used in this study

\begin{tabular}{llc}
\hline CGCM & Research Center & Resolution $\left({ }^{\circ}\right)$ \\
\hline CGCM3.1(T63) & Canadian Centre for Climate Modeling and Analysis, Canada & $\sim 2.8 \times 2.8$ \\
CSIRO_MK3.5 & Commonwealth Scientific and Industrial Research Organization Atmospheric Research, Australia & $1.875 \times 1.875$ \\
GFDL_CM2.1 & Geophysical Fluid Dynamics Laboratory(GFDL), United States & $2.0 \times 2.5$ \\
ECHAM5/MPI-OM & Max Planck Institute for Meteorology, Germany & $1.875 \times 1.875$ \\
NCAR_CCSM3.0 & National Center for Atmospheric Research, United States & $1.4 \times 1.4$ \\
NCAR_PCM1 & National Center for Atmospheric Research, United States & $\sim 2.8 \times 2.8$ \\
UKMO-HadCM3 & Hadley Centre for Climate Prediction and Research/Met Office, United Kingdom & $2.5 \times 3.75$ \\
& &
\end{tabular}

Daily precipitation datasets were extracted from the National Climatic Data Center from 1970 to 1999 for 25 stations within the area of MLRA 41 as a baseline condition for assessing the change in future climate predictions (figure 1). These stations have at least 30 years of records and have been subjected to the standard National Climatic Data Center data checks. The locations of those 25 stations were associated with GCM grid cells to extract projected precipitation for the study area.

Climate Change Emission Scenarios. To estimate the potential future climate, we used data from the recent IPCC Fourth Assessment Report coupled ocean-atmosphere GCM simulations (IPCC 2007). Recent studies showed that the multimodel ensemble simulated reasonably well both annual precipitation and annual cycles (IPCC 2007). Therefore, seven GCMs were used to obtain the monthly precipitation (table 2). To represent the different greenhouse gas (GHG) emission scenarios, three nonmitigated IPCC Special Report on Emission Scenarios, A2, A1B, and B1, were selected. The three emission scenarios represent high, medium, and low GHG scenarios (IPCC 2007), respectively. The emission scenarios were implemented for all seven models during two time slices of thirty years each, from 2030 through 2059 and from 2070 through 2099. To calibrate the GCM results, we also collected GCM output data from the "Climate of the 20th Century" experiment $(20 \mathrm{C} 3 \mathrm{M})$ in the same database, which simulates climate conditions during 1850 to 2000 that were driven by the preindustrial GHG emissions (IPCC 2007). The 20C3M run during 1970 to 1999 was used as the baseline period for calibration with historical observed data for future changes.

Spatial and Temporal Downscaling. There exists spatial and temporal scale mismatch between GCM projections and pointscale impact assessment of climate change
(Murphy 1999). The spatial resolution of the GCM is often coarser than that needed for assessing local impacts of climate change on natural resources. Therefore, a spatiotemporal downscaling process (Zhang 2005, 2007) was used to downscale monthly precipitation of GCM projections at scale of GCM grid boxes to the specific weather stations. Here we summarize the downscaling processes. The details can be found in Zhang (2005, 2007) and Zhang et al. (2010). Two steps were included in the downscaling processes: spatial and temporal downscaling.

The spatial downscaling process was performed between a station and a GCM-grid box containing the station. For each calendar month, regression functions were derived between observed monthly precipitation data during 1970 to 1999 and the corresponding data from 20C3M. Hence, the monthly precipitation amounts of 1970 to 1999 from the 20C3M experiment were used as the control, and the historical monthly data of the same period were used as the baseline climate condition. Then, the regression functions were applied to the GCM-projected future precipitation of each month. For each calendar month, 30-year-downscaled monthly precipitation values were obtained at each station for the two future time slices. Then, the monthly means and variances of the future climate at each station were calculated (Wilks 1999; Zhang 2005, 2007).

After developing future monthly climate estimates for each station, the CLImate GENerator (CLIGEN) (Nicks and Gander 1994) was used to generate long-term daily weather series representing the altered climates. Temporal downscaling was done in order to estimate the four CLIGEN precipitation input parameters that required adjustment for running CLIGEN to generate future daily weather series: $R_{d}$, daily mean precipitation; $\sigma_{d}^{2}$, the variance of daily precipitation for wet days (i.e., days with nonzero precipitation); $P_{w / d}$, conditional tran- sition probabilities of a wet day following a dry day; and $P_{w / w}$, conditional transition probabilities of a wet day following a wet day. The baseline CLIGEN input parameters were determined by measured daily weather data of 1970 to 1999 at each station.

To determine $P_{w / w}$ and $P_{w / d}$, we separated the 30 years of observed data into two groups with the 15 wettest and driest months in each group, based on the rank of daily precipitation values, and calculated the $P_{w / w}$ and $P_{w / d}$ for each group (Zhang 2007). A linear relationship between $P_{w / w}$ and mean monthly precipitation $\left(R_{m}\right)$, as well as the relationship between $P_{w / d}$ and $R_{m}$, were developed based on two pairs of data points. Future conditional transition probabilities of precipitation were estimated from this linear relationship. With the two transition probabilities, mean daily precipitation $\left(R_{d}\right)$ and daily precipitation variance $\left(\sigma_{d}^{2},\right)$ for wet days were calculated. See details for the calculation process in Zhang $(2005,2007)$ and Zhang et al. (2010).

Finally, all parameters at each station were adjusted separately for each climate change scenario. These adjusted parameters were then input to CLIGEN (V5.22564), and 100 years of daily series data were generated for each station under each climate change scenario and each GCM in order to obtain a stable running average of annual soil loss (Baffaut et al. 1996). Then, the outputs from CLIGEN were formatted to climate input files for the soil erosion model.

Soil Erosion Modeling. The Rangeland Hydrology and Erosion Model (RHEM) (Nearing et al. 2011) was used to calculate runoff and soil loss at the hillslope scale for each of the 151 sample points. The RHEM model computes soil loss along a hillslope and sediment yield at the end of a hillslope. RHEM was developed by the USDA Agricultural Research Service and based on data collected from rangeland erosion experiments (Nearing et al. 2011; Weltz et al. 2008). RHEM is an event-based erosion predic- 
Table 3

Predicted mean annual precipitation, runoff, and soil loss averaged across the study area and the spatial mean percentage changes, as simulated by the seven models under the three emission scenarios relative to baseline of 1970 to 1999.

\begin{tabular}{|c|c|c|c|c|c|c|c|}
\hline Scenario & & $\begin{array}{l}\text { Precipitation } \\
\text { (mm [\%]) }\end{array}$ & $\begin{array}{l}\text { Runoff } \\
\text { (mm [\%]) }\end{array}$ & $\begin{array}{l}\text { Soil loss } \\
\text { rate (t ha-1 }[\%])\end{array}$ & $\begin{array}{l}\text { Precipitation } \\
\text { (mm [\%]) }\end{array}$ & $\begin{array}{l}\text { Runoff } \\
\text { (mm [\%]) }\end{array}$ & $\begin{array}{l}\text { Soil loss } \\
\text { rate (t ha-1 }[\%])\end{array}$ \\
\hline \multicolumn{2}{|l|}{ Baseline } & 404 & 20.67 & 0.20 & 404 & 20.67 & 0.20 \\
\hline \multicolumn{8}{|l|}{$\mathrm{A} 2$} \\
\hline & CGCM3.1 & $440(+8.9)$ & $54.93(+165.7)$ & $0.63(+222.1)$ & $338(-16.2)$ & $41.50(+100.7)$ & $0.56(+186.9)$ \\
\hline & MK3.5 & $481(+19.1)$ & $45.02(+117.8)$ & $0.44(+121.9)$ & $434(+7.5)$ & $48.01(+132.2)$ & $0.61(+210.4)$ \\
\hline & ECHAM5 & $386(-4.4)$ & $27.76(+34.3)$ & $0.31(+57.8)$ & $373(-7.6)$ & $34.61(+67.4)$ & $0.43(+120.9)$ \\
\hline & ccsm3.0 & $440(+9.0)$ & $43.83(+112.0)$ & $0.47(+138.4)$ & $432(+7.0)$ & $48.04(+132.4)$ & $0.59(+199.2)$ \\
\hline & PCM1 & $388(-3.8)$ & $29.99(+45.1)$ & $0.36(+81.8)$ & $421(+4.2)$ & $45.52(+120.2)$ & $0.60(+207.2)$ \\
\hline & HadCM3 & $410(+1.5)$ & $33.94(+64.2)$ & $0.48(+144.3)$ & $443(+9.8)$ & $30.85(+49.2)$ & $0.33(+69.2)$ \\
\hline & Mean & $423(+4.9)$ & $39.28(+90.0)$ & $0.45(+129.3)$ & $399(-1.1)$ & $39.63(+91.7)$ & $0.51(+157.1)$ \\
\hline & ECHAM5 & $373(-7.7)$ & $31.96(+54.6)$ & $0.37(+86.4)$ & $331(-17.9)$ & $33.53(+62.2)$ & $0.47(+139.9)$ \\
\hline & ccsm3.0 & $418(+3.6)$ & $32.10(+55.3)$ & $0.33(+67.8)$ & $399(-1.2)$ & $40.43(+95.6)$ & $0.46(+134.1)$ \\
\hline & PCM1 & $451(+11.6)$ & $40.36(+95.2)$ & $0.51(+159.7)$ & $379(-6.2)$ & $41.85(+102.5)$ & $0.59(+198.2)$ \\
\hline & HadCM3 & $418(+3.5)$ & $34.67(+67.7)$ & $0.46(+131.9)$ & $457(+13.1)$ & $28.25(+36.6)$ & $0.31(+56.0)$ \\
\hline & Mean & $417(+3.2)$ & $38.65(+87.0)$ & $0.48(+143.4)$ & $400(-1.0)$ & $37.92(+83.4)$ & $0.47(+140.5)$ \\
\hline \multicolumn{8}{|l|}{ B1 } \\
\hline & CGCM3.1 & $399(-1.3)$ & $28.10(+35.9)$ & $0.30(+53.6)$ & $422(+4.6)$ & $48.49(+134.6)$ & $0.59(+201.0)$ \\
\hline & MK3.5 & $479(+18.6)$ & $46.62(+125.5)$ & $0.47(+139.8)$ & $455(+12.6)$ & $44.08(+113.2)$ & $0.56(+183.5)$ \\
\hline & CM2.1 & $365(-9.5)$ & $29.41(+42.3)$ & $0.33(+67.0)$ & $429(+6.2)$ & $29.95(+44.9)$ & $0.34(+71.5)$ \\
\hline & ECHAM5 & $372(-7.8)$ & $40.66(+96.7)$ & $0.60(+206.2)$ & $401(-0.7)$ & $35.30(+70.7)$ & $0.43(+119.0)$ \\
\hline
\end{tabular}

Note: Numbers in parentheses indicate percentage change from baseline values.

tion tool specific for rangeland application, and was developed through new equations derived from rangeland data (Nearing et al. 2011). RHEM used a newly developed splash erosion and thin sheet-flow transport equation to capture dominant erosion processes on undisturbed rangelands. The dominant erosion processes are affected by the type of plant growth forms present at a site (Wei et al. 2009). A new system of estimating hydrologic and erosion parameters with rangeland plant communities was developed based on 204 plots in 49 rangeland sites distributed across 15 western US states (Wei et al. 2009). The parameters that can be estimated in this system include the Green-Ampt hydraulic conductivity $\left(k_{e}\right)$, the splash and sheet erosion coefficient $\left(k_{s s}\right)$, the friction factors for runoff $\left(r_{f}\right)$, and the friction factors for ero- sion $\left(r_{e}\right)$. These are the required input values that are hard to measure directly, and all the equations were developed based on RHEM rangeland database. RHEM is parameterized based on plant growth habitat classification using the data that are typically collected for rangeland management purposes. The plant growth habitat groups include annual grass and forbs, bunch grass, shrubs, and sod grass.

The model calibration was made with independent experimental data by Wei et al. (2009) and Nearing et al. (2011) from rainfall simulation experiments in southern Arizona. The coefficients of determination $\left(r^{2}\right)$ for runoff and erosion predictions were 0.87 and 0.50 compared to observed values, which indicated that RHEM is able to reasonably predict runoff and soil loss for rangeland conditions (Nearing et al. 2011).
The RHEM model requires 13 input parameters that are grouped in the four categories of slope profile, soils, vegetation type and cover, and climate (Wei et al. 2009). The data used in this project for each of the 151 points were percentage canopy cover, percentage ground cover (consisting of litter in touch with the ground surface, rock fragment, and basal vegetation area), and slope gradient. Sand and clay percentage within the top $5 \mathrm{~cm}$ (2 in) soil layer depth were calculated from the SSURGO soil database. Slope and soil input parameters were calculated from the database at each sample point. The most dominant plant growth habitat was determined for each sampling site, and the appropriate equation as described by Nearing et al. (2011) was selected to estimate hydraulic conductivity $\left(k_{e}\right)$ and the 


\section{Figure 2}

Mean annual precipitation averaged over the area during 1970 to 1999 and that during 2030 to 2059 and 2070 to 2099 under three emission scenarios (A2, A1B, and B1). Each value is the mean of seven models ( \pm standard error) for the two future periods.

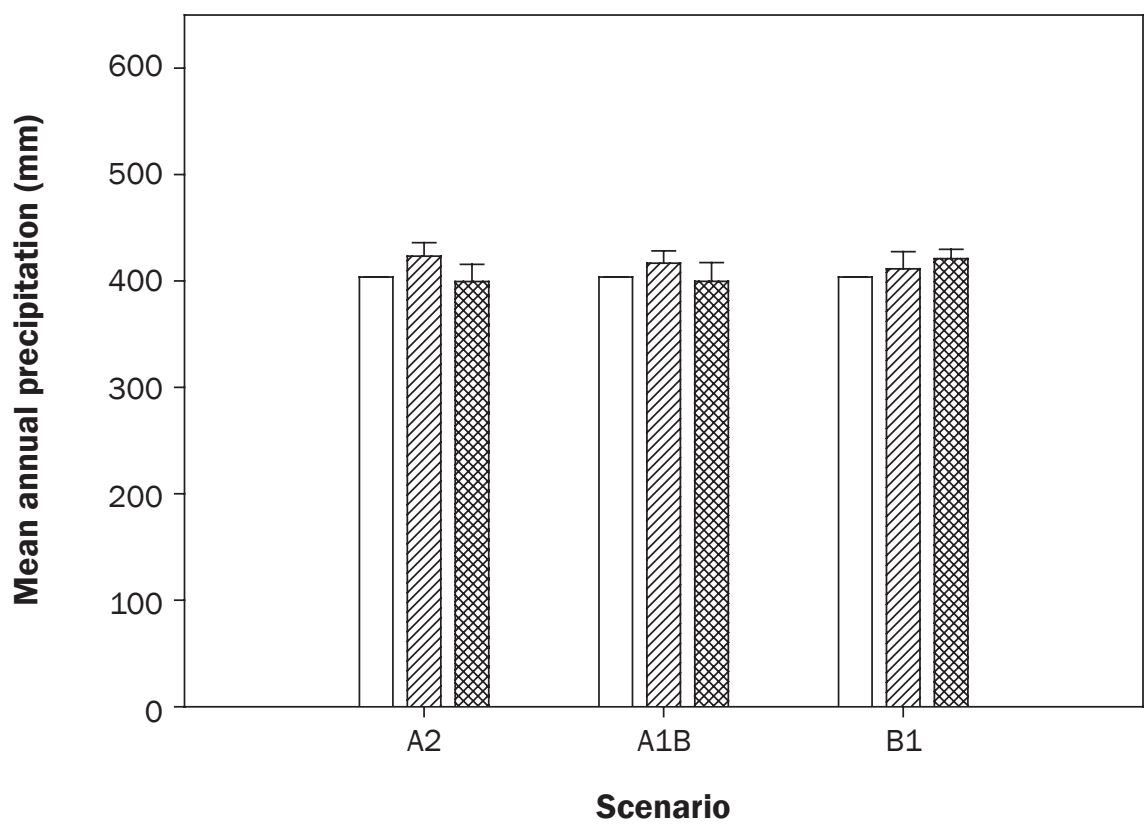

Legend splash and sheet erosion coefficient $\left(k_{s s}\right)$. The hydraulic conductivity and the splash and sheet soil erodibility coefficient, which are key parameters in RHEM to estimate runoff and soil erosion, were estimated using vegetation cover properties and soil sand and clay content gathered from the SSURGO soil databases (Nearing et al. 2011).

The 25 CLIGEN stations across the MLRA 41 were linked to the sampling points by means of Thiessen polygons. That is, sampling points within each polygon were provided with a time series of 100 years of stochastically generated rainfall data using the CLIGEN (Nicks and Gander 1994). Current and future climate input files were built based on the method stated above. Simulations were made for current conditions with sampled vegetation information and observed climate during 1970 to 1999 and for future conditions with projected climate during 2030 to 2059 and 2070 to 2999 , assuming similar vegetation for each period.

Heavy Precipitation Events. In order to assess the effects of heavy precipitation events on runoff and soil loss, the frequency and intensity of heavy to extreme precipitation events during the current and two future time slices were analyzed. Here, we used event frequency thresholds of daily total rainfall depth to define heavy precipitation events and intensity levels (Karl and Knight 1998). For a given location, we defined daily heavy precipitation thresholds at the 95th and 99th percentiles of the distribution during the historical period of 1970 through 1999. Then, the average frequency and the proportion of total annual precipitation coming from heavy precipitation events were compared between the two future time slices and the historical period. In other words, the 95th and 99th percentiles of daily heavy precipitation amounts were compared for the three periods of 1970 to 1999,2030 to 2059 , and 2070 to 2099 to study the changes in heavy precipitation intensity.

A $t$-test and Duncan's multiple range tests were used to determine significant differences in mean precipitation, runoff and soil loss changes among the models, emission scenarios, and periods using the SAS program (SAS Institute Inc. 2003).

\section{Results and Discussion}

Projected Precipitation Changes. Table 3 presents individual model-projected mean annual precipitation and its changes averaged over the study area during the two projected future periods under the three emission scenarios. No consistent changes in mean annual precipitation were projected among the seven models across the three emission scenarios during the two future periods. This indicated that uncertainty about the projected changes in annual precipitation is large and the changes do not scale consistently across the different climate change models and emission scenarios.

Overall, there were no statistically significant changes ( $t$-test, $\alpha=0.05)$ under all three emission scenarios for both future time slices compared to the observed mean precipitation of $404 \mathrm{~mm}$ (15.9 in) during the period of 1970 to 1999 (figure 2). Meanwhile, when comparing changes in the distribution of the average annual precipitation amounts for all the sample points between historical and future periods (figure 3), no readily observable shifts were found between the historical distribution and future distributions under the three emission scenarios. Similar results were found for the period of 2070 to 2099 (not shown). There were 109 of 151 sample points in which annual precipitation was less than $400 \mathrm{~mm}$ (15.7 in) during the period of 1970 to 1999 , and that number was 106,108, and 108 for the A2, A1B, and B1 emission scenarios, respectively, during 2030 to 2099 , and 109,109 , and 106 during 2070 to 2099 (table 4). This also indicated no significant changes (Duncan test, $\alpha=0.05$ ) across the area as a whole in the future cases.

In order to analyze seasonal changes in precipitation, two seasons were defined for a year: summer and winter. Winter months were from November through May, and summer months were from June through October. Figure 4 shows results for projected seasonal changes in precipitation, averaged across the seven GCM outputs and the study area. In the summer, projected precipitation showed increases of $5 \%$ to $8 \%$ during both future periods under all three emission scenarios. These increases in precipitation were not significantly different among the three emission scenarios using a Duncan means test $(\alpha=0.05)$ (figure $4 \mathrm{a})$. In the winter, by the middle of the current century, precipitation showed almost no change under the three scenarios (figure $4 b$ ). By the end of the current century, projected winter precipitation dropped $8 \%$ and $10 \%$ under $\mathrm{A} 2$ and $\mathrm{A} 1 \mathrm{~B}$ scenarios, while precipitation had no change 


\section{Figure 3}

Histograms of average annual precipitation for (a) the historical observed data during 1970 to 1999 across the 151 sample points and for (b) A2, (c) A1B, and (d) B1, the three emission scenarios for the time periods of 2030 to 2059.

(a)

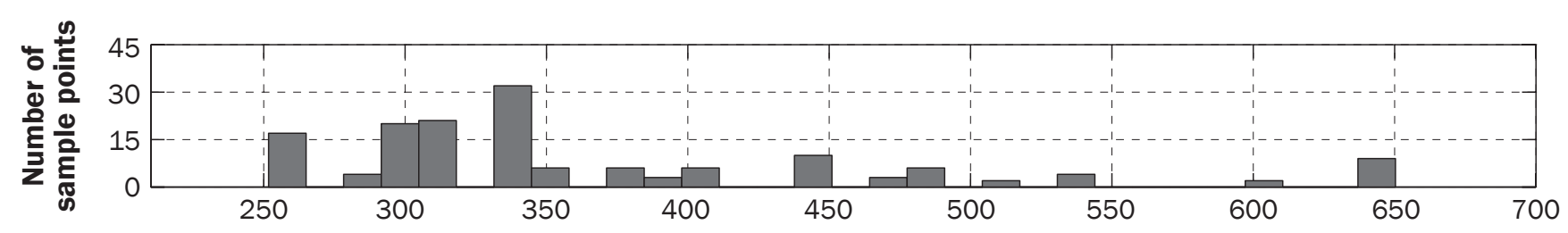

(b)

Annual precipitation (mm)

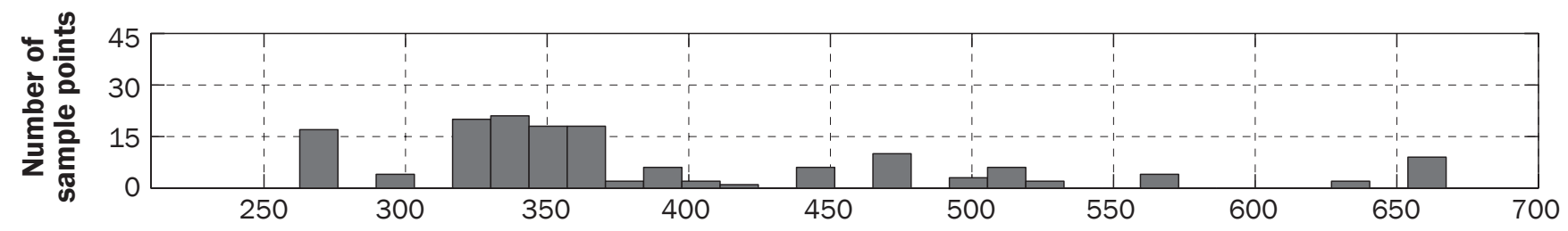

(c)

Annual precipitation (mm)

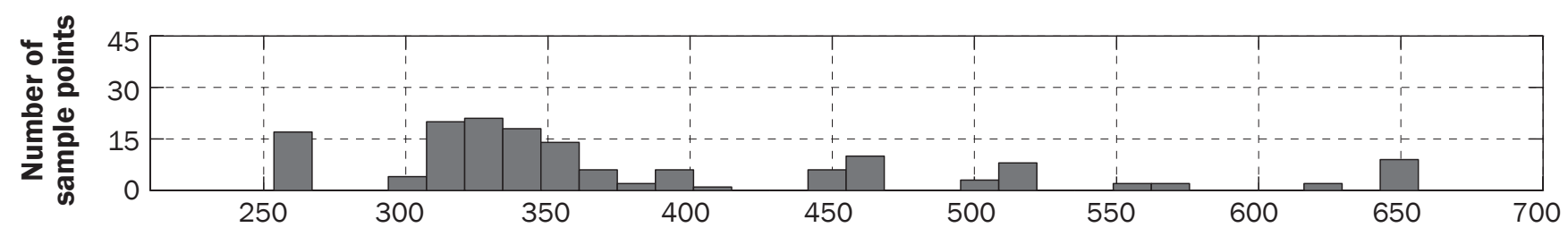

(d)

Annual precipitation $(\mathrm{mm})$

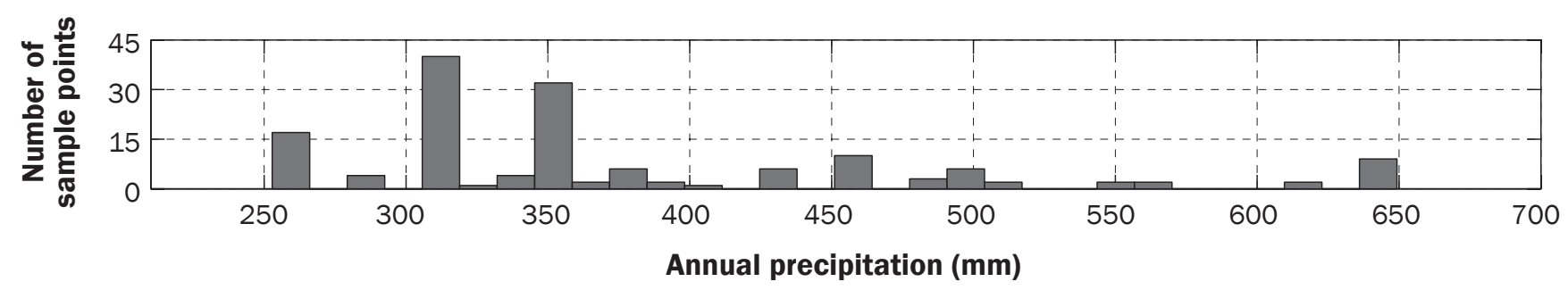

under the B1 emission scenario (figure 4b). The declining trends of winter precipitation are consistent with other studies by Seager et al. $(2007,2010)$, who reported decreases in winter precipitation under A1B scenario in the southwestern North America.

With no net significant changes in mean annual precipitation amounts, however, precipitation regimes would become more extreme. As seen in figure 5, the frequency of extreme events both at the 95th and 99th percentile would increase significantly for all emission scenarios during the two future periods compared to that for the period from 1970 to 1999 ( $t$-test, $\alpha=0.05$ ). Similar trends were found for the fraction of total annual precipitation coming from extreme events (figures $5 \mathrm{c}$ and $5 \mathrm{~d}$ ). In addition, projected precipitation intensity averaged over the area at the upper percentile were also significantly greater $(\alpha=0.05)$ than those for the period 1970 to 1999 in all cases (table 5). On the other hand, significant reductions $(\alpha$ $=0.05$ ) in the number of wet days per year compared to the historically observed period of 1970 to 1999 were projected for both the 2050s and 2090s under all three emission scenarios (table 5). The trends of more extreme events are consistent with previous studies for precipitation changes in the last century (Easterling et al. 2000).

Projected Runoff and Soil Loss Changes. Understanding and predicting the potential changes of runoff and soil erosion in range- lands under an altered precipitation pattern is of importance to assess the impacts of climate change on mitigation with management practices in the future. Unlike the inconsistency in precipitation changes among the models and emission scenarios, changes in mean annual runoff and soil loss averaged across the study area were all projected to increase in all the models by the 2050s and 2090 s, irrespective of the emission scenario selected (table 3).

Though spatial-averaged annual precipitation did not show great changes, projected annual runoff averaged over the area was significantly greater ( $t$-test, $\alpha=0.05)$ than that for the period of 1970 to1999 in all cases (table 3 and figure 6a). Overall, the results 
Figure 4

Changes in mean (a) summer and (b) winter precipitation during 2030 to 2059 and 2070 to 2099 relative to 1970 to 1999 under three emission scenarios ( $A_{2}, A_{1} B$, and $\left.B_{1}\right)$. Each value is the mean of seven models averaged over the region ( \pm standard error).

(a)

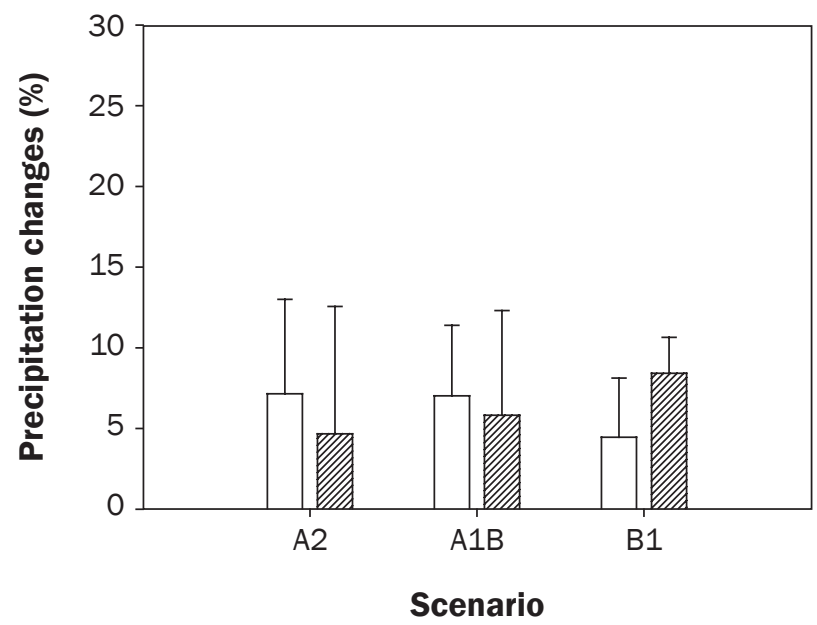

(b)

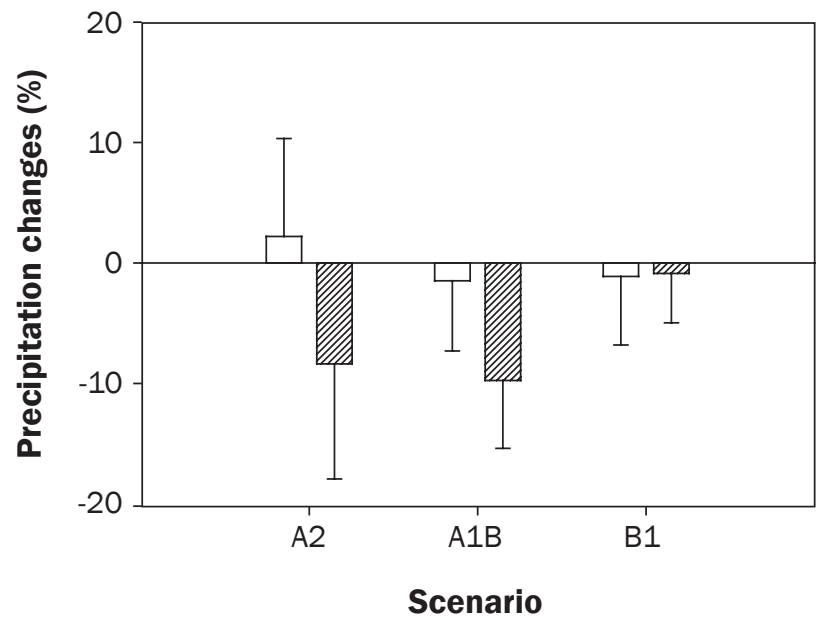

Legend

2030 to 2059

2070 to 2099

Table 4

Number of sample points in three categories of precipitation, runoff, and soil loss for the historical period and the two future periods under three emission scenarios.

\begin{tabular}{|c|c|c|c|c|c|c|c|}
\hline \multirow[b]{2}{*}{ Variable } & \multirow[b]{2}{*}{1970 to 1999} & \multicolumn{3}{|c|}{2030 to 2059} & \multicolumn{3}{|c|}{2070 to 2099} \\
\hline & & A2 & A1B & B1 & A2 & A1B & B1 \\
\hline \multicolumn{8}{|c|}{ Annual precipitation ( $\mathrm{mm}$ ) } \\
\hline$<400$ & $109 a$ & $106 a$ & $108 a$ & $108 a$ & $109 a$ & $109 a$ & $106 a$ \\
\hline 400 to 600 & $33 a$ & $34 a$ & $32 a$ & $32 a$ & $33 a$ & $33 a$ & $34 a$ \\
\hline$>600$ & $9 a$ & $11 a$ & $11 \mathrm{a}$ & $11 a$ & $9 a$ & $9 a$ & $11 a$ \\
\hline \multicolumn{8}{|c|}{ Annual runoff (mm) } \\
\hline$<40$ & $114 a$ & $88 b$ & $89 b$ & $92 b$ & $85 b$ & $91 b$ & $96 b$ \\
\hline 40 to 80 & $35 a$ & $36 a$ & $39 a$ & $34 a$ & $39 a$ & $37 a$ & $33 a$ \\
\hline$>80$ & $2 a$ & $27 b$ & $23 b$ & $25 b$ & $27 \mathrm{~b}$ & $23 b$ & $22 \mathrm{~b}$ \\
\hline \multicolumn{8}{|c|}{ Annual soil loss (t ha-1) } \\
\hline$<0.5$ & $137 a$ & $122 b$ & $121 b$ & $121 b$ & $119 b$ & $124 b$ & $126 b$ \\
\hline 0.5 to 2.0 & $13 a$ & $26 b$ & $27 b$ & $27 b$ & $29 b$ & $24 b$ & $22 b$ \\
\hline$>2.0$ & $1 a$ & $3 b$ & $3 b$ & $3 b$ & $3 b$ & $3 b$ & $3 b$ \\
\hline
\end{tabular}

Note: Numbers with the same letter within a row are not significantly different from each other at $\alpha=0.05$ (Duncan test).

here show an increase of between $86 \%$ and $90 \%$ in annual runoff under the three emission scenarios by the 2050 s, with a standard deviation (sd) of $41 \%$ to $59 \%$, and an increase of between $79 \%$ and $92 \%$ by the 2090 s, with a sd of $39 \%$ to $47 \%$ (figure $6 a$ ). Mean changes in annual runoff were not significantly different among the emission scenarios and periods (Duncan test, $\alpha=0.05$ ). The increases in the increased on two cropland sites in Temple, Texas, and Pierre, South Dakota.

As for annual soil loss, the trends in scenario-averaged, projected changes followed the same basic pattern as did the trends in annual runoff (figure 6). Projected soil loss values were also significantly greater $(\alpha=$ 0.05) than those for the period 1970 to1999 in all cases, and these increases were greater than that for runoff (figure 6). Mean annual soil loss increased by $129 \%$ to $143 \%$ (sd of $52 \%$ to $104 \%$ ) under the three emission scenarios by the 2050 s, and increased by $127 \%$ to $157 \%$ (sd of $56 \%$ to $67 \%$ ) by the 2090 s (figure 6b). It is also noteworthy that annual soil loss rates are $0.2 \mathrm{t} \mathrm{ha}^{-1}\left(0.09 \mathrm{tn} \mathrm{ac}^{-1}\right)$ averaged over the study area during 1970 to 1999 and 0.45 to $0.51 \mathrm{t} \mathrm{ha}^{-1}\left(0.2\right.$ to $\left.0.23 \mathrm{tn} \mathrm{ac}^{-1}\right)$ for all the scenario combinations in the future periods (figure 6b), which fall within the values reported in previous studies (Nearing et al. 2007; Ritchie et al. 2009; Polyakov et al. 2010b). The high sensitivity of runoff and soil loss to climate changes can be explained by the fact that they are dependent on changes in storm patterns. Greater increases of soil loss indicated that soil erosion is more sensitive to changes in storm patterns than runoff. These results also imply that the impacts of changes in climate influence runoff and soil loss in a nonlinear way.

The dramatic increases in runoff and soil loss were attributed to the increase in the 


\section{Figure 5}

Mean annual frequency of and fraction of total annual precipitation coming from extreme events defined as the (a and c) 95 th and (b and d) 99 th percentile of daily rainfall amount for the time periods of 1970 to 1999 and the two projected periods of 2030 to 2059 and 2070 to 2099 under three emission scenarios ( $A 2, A_{1} B$, and $\left.B 1\right)$. Each value is the mean of seven models ( \pm standard error) for the two future periods.

(a)

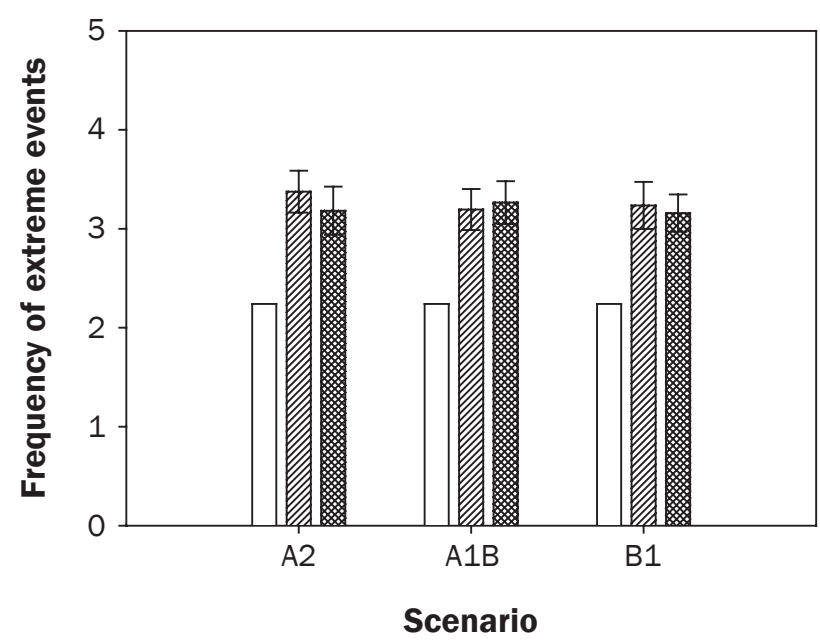

(c)

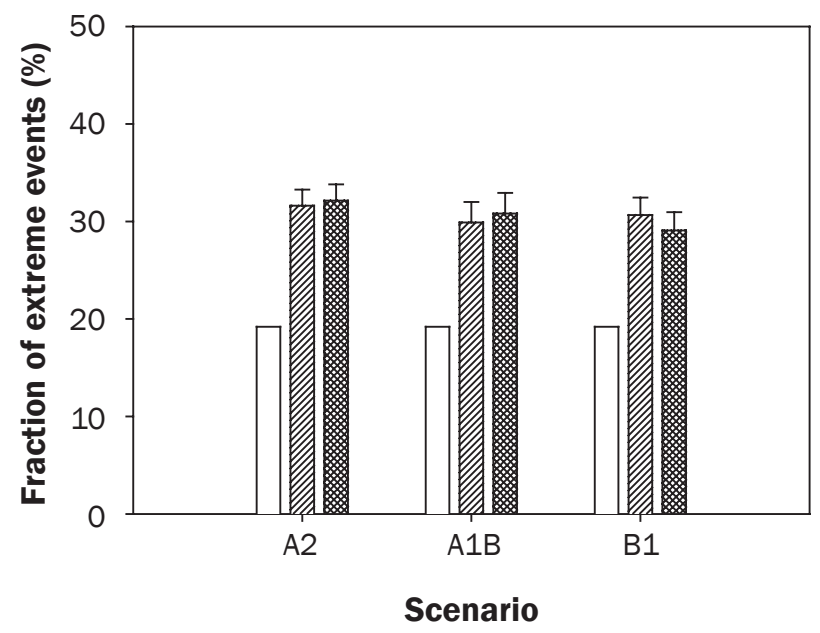

(b)

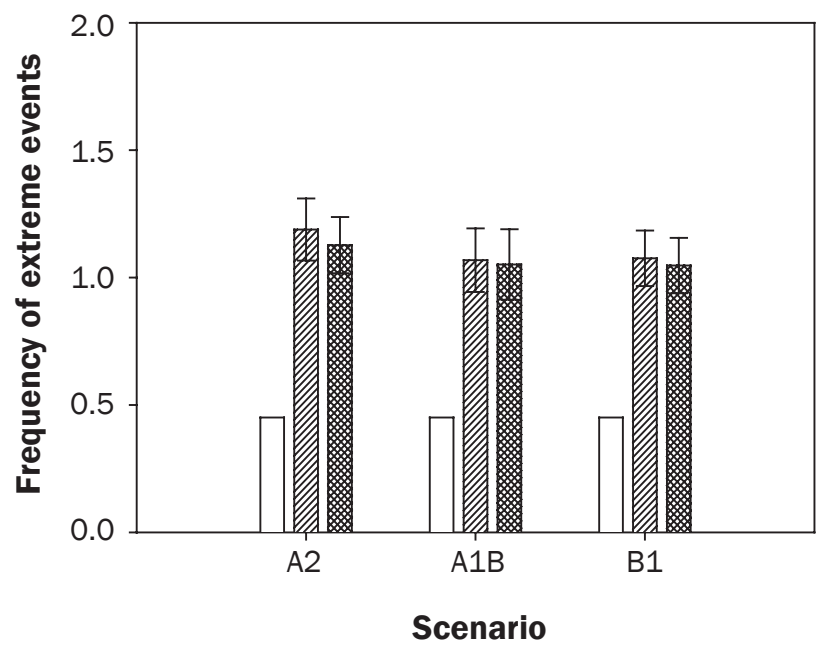

(d)

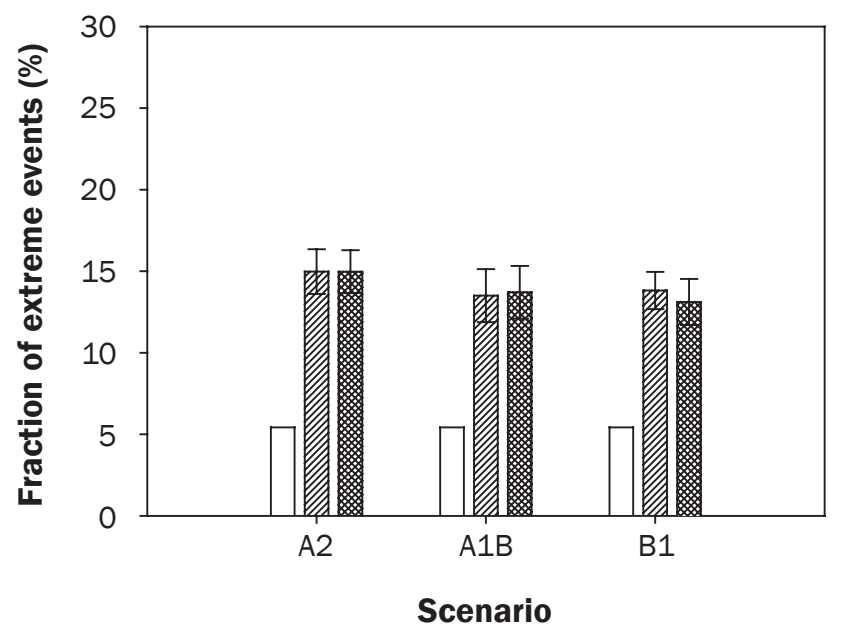

Legend

frequency and intensity of extreme rainfall events since there was no significant change in annual precipitation and extreme events play a key role in causing sediment yields. As a result of more extreme events, runoff and soil loss would obviously increase during the two future periods. Table 6 shows that more than $70 \%$ of total runoff and soil loss was caused by extreme rainfall events greater than the 95th percentile event size in all cases. Sediment production rates in semiarid rangeland environments are generally produced by high magnitude, low frequency rainfall events (Nearing et al. 2007). Polyakov et al. (2010a) analyzed long-term (34 years) runoff and soil loss data from semiarid rangeland watersheds in southern Arizona and found that the largest $10 \%$ of storms produced over $50 \%$ of total soil loss. Hence, this trend toward more extreme events was the main cause for the projected increase in the predicted runoff and soil erosion. These results coincide with a previous study by Nearing et al. (2005) that found that changes in rainfall intensity are likely to have significant impact on runoff and soil erosion.
Seasonal changes in runoff and soil loss were also analyzed (figure 7). As seen in figure $7 \mathrm{a}$, runoff in the summer significantly increased in the future emission scenarios compared to the baseline $(\alpha=0.05)$. RHEM predicted similar runoff changes for all the combinations of models and climate scenarios in the study area, varying from 55\% to $68 \%$. Contrary to the reduction in precipitation in the winter for future scenarios, winter runoff was projected to be markedly greater than that for the period 1970 to 1999 in all cases (figure $7 \mathrm{~b}$ ). This increase was 
Table 5

Statistics of regional average CLIGEN-generated daily precipitation for days with $>1 \mathrm{~mm} \mathrm{~d}^{-1}$ for all the emission scenarios. The data for the mean number of wet days per year $(\mathrm{Nd})$, mean percentage of total precipitation from extreme events (PrcP), and precipitation intensity at specific quantiles (PInt) are shown below.

\begin{tabular}{|c|c|c|c|c|c|c|c|}
\hline \multirow[b]{2}{*}{ Variable } & \multirow[b]{2}{*}{1970 to 1999} & \multicolumn{3}{|c|}{2030 to 2059} & \multicolumn{3}{|c|}{2070 to 2099} \\
\hline & & A2 & A1B & B1 & A2 & A1B & B1 \\
\hline $\mathrm{Nd}, \geq 1\left(\mathrm{~mm} \mathrm{~d}^{-1}\right)$ & $44.82 \mathrm{a}$ & $39.10 b$ & $39.34 b$ & $38.10 b$ & $36.15 b$ & $36.65 b$ & $39.86 b$ \\
\hline $\mathrm{Nd}, \geq 95$ percentile $(\mathrm{d})$ & $2.25 a$ & $3.37 b$ & $3.19 b$ & $3.24 b$ & $3.26 b$ & $3.18 b$ & $3.16 b$ \\
\hline $\mathrm{Nd}, \geq 99$ percentile $(\mathrm{d})$ & $0.45 a$ & $1.19 b$ & $1.07 \mathrm{~b}$ & $1.08 b$ & $1.13 b$ & $1.05 b$ & $1.05 b$ \\
\hline PrcP, $\geq 95$ percentile (\%) & $19.20 \mathrm{a}$ & $31.62 b$ & $29.90 b$ & $30.67 \mathrm{~b}$ & $32.13 b$ & $30.81 b$ & $29.08 b$ \\
\hline PrcP, $\geq 99$ percentile (\%) & $5.42 a$ & $14.97 b$ & $13.50 \mathrm{~b}$ & $13.81 \mathrm{~b}$ & $14.97 b$ & $13.71 b$ & $13.11 b$ \\
\hline PInt, 95 percentile $\left(\mathrm{mm} \mathrm{d}^{-1}\right)$ & $26.45 a$ & $35.10 b$ & $34.00 \mathrm{~b}$ & $34.14 b$ & $35.71 b$ & $34.87 \mathrm{~b}$ & $33.45 b$ \\
\hline PInt, 99 percentile $\left(\mathrm{mm} \mathrm{d}^{-1}\right)$ & $42.82 \mathrm{a}$ & $63.67 \mathrm{~b}$ & $60.40 \mathrm{~b}$ & $60.86 \mathrm{~b}$ & $64.44 b$ & $61.01 \mathrm{~b}$ & $59.72 b$ \\
\hline
\end{tabular}

Note: Numbers with the same letter within a row are not significantly different from each other at $\alpha=0.05$ (Duncan test).

\section{Figure 6}

Mean annual (a) runoff and (b) soil loss averaged over the area during the projected time periods of 2030 to 2059 and 2070 to 2099 relative to 1970 to 1999 under the three emission scenarios ( $A_{2}, A_{1} B$, and $\left.B_{1}\right)$. Each value is the mean of seven models averaged over the region ( \pm standard error).

(a)

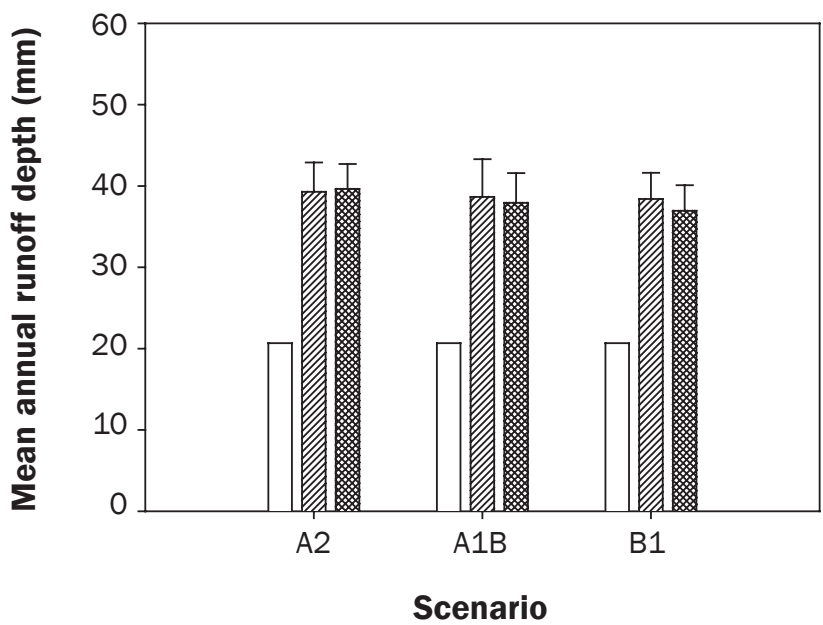

(b)

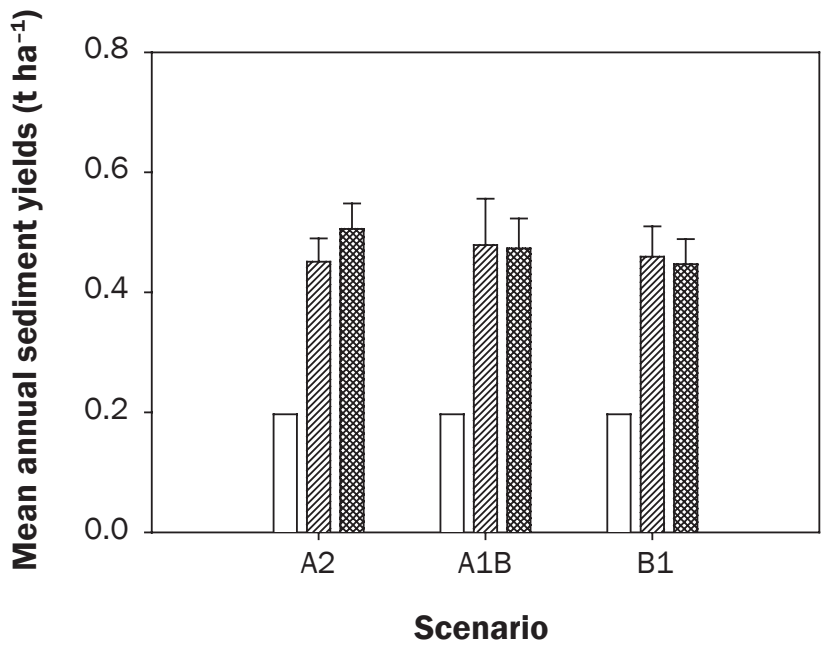

Legend

\section{Table 6}

Aerially averaged percentage of total mean annual runoff and soil loss caused by extreme (>95th and 99 th percentile) events during the periods of 1970 to 1999, 2030 to 2059 (projected), and 2070 to 2099 (projected) under the three emission scenarios (A2, A1B, and B1). Numbers in parentheses are the standard deviation of seven GCM models. PrctRunoff95 (PrctRunoff99) is the percentage of total runoff caused by events greater than the 95th (99th) percentile event size. PrctSed95 (PrctSed99) is the percentage of total soil loss caused by events greater than the 95th (99th) percentile event size.

\begin{tabular}{|c|c|c|c|c|c|c|c|}
\hline PrctRunoff95 (\%) & 73 & $84(4)$ & $83 \%(3)$ & $83(3)$ & $83(3)$ & $82(4)$ & $82(4)$ \\
\hline PrctSed95 (\%) & 76 & $88(3)$ & $88 \%(3)$ & $88(2)$ & $88(3)$ & $88(3)$ & $87(2)$ \\
\hline PrctRunoff99 (\%) & 34 & $57(7)$ & $55 \%(7)$ & $54(5)$ & $55(7)$ & $53(8)$ & $54(7)$ \\
\hline PrctSed99 (\%) & 40 & $64(7)$ & $64 \%(9)$ & $62(6)$ & $63(7)$ & $62(7)$ & $64(6)$ \\
\hline
\end{tabular}




\section{Figure 7}

Changes in mean (a) summer runoff, (b) winter runoff, (c) summer soil loss, and (d) winter soil loss during the time periods of 2030 to 2059 and 2070 to 2099 relative to the period 1970 to 1999 under the three emission scenarios (A2, A1B, and B1). Each value is the mean of seven models averaged over the region ( \pm standard error).

(a)

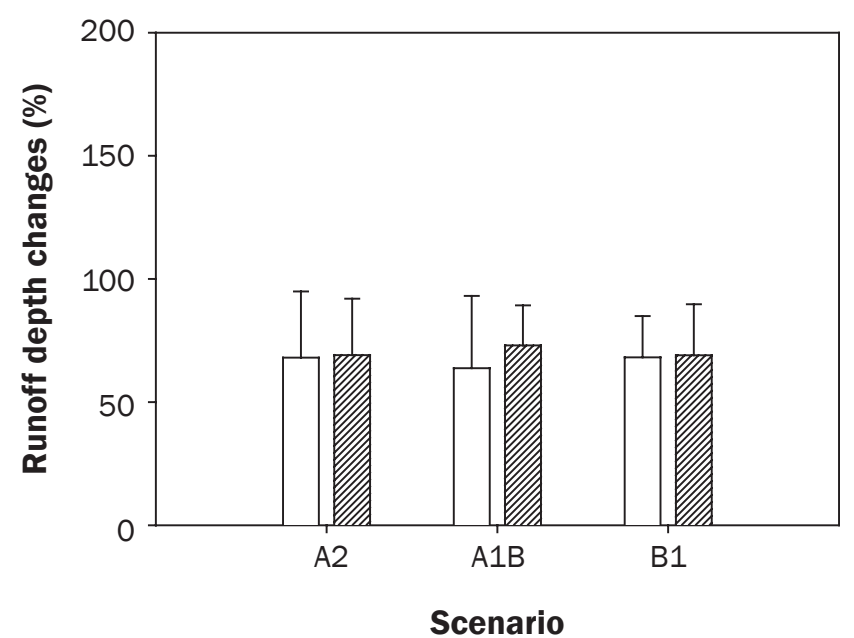

(c)

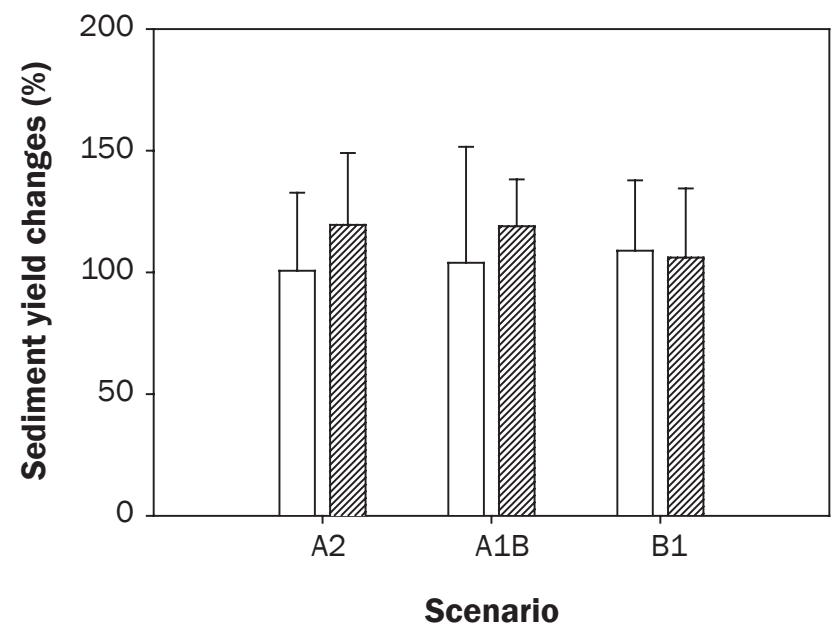

(b)

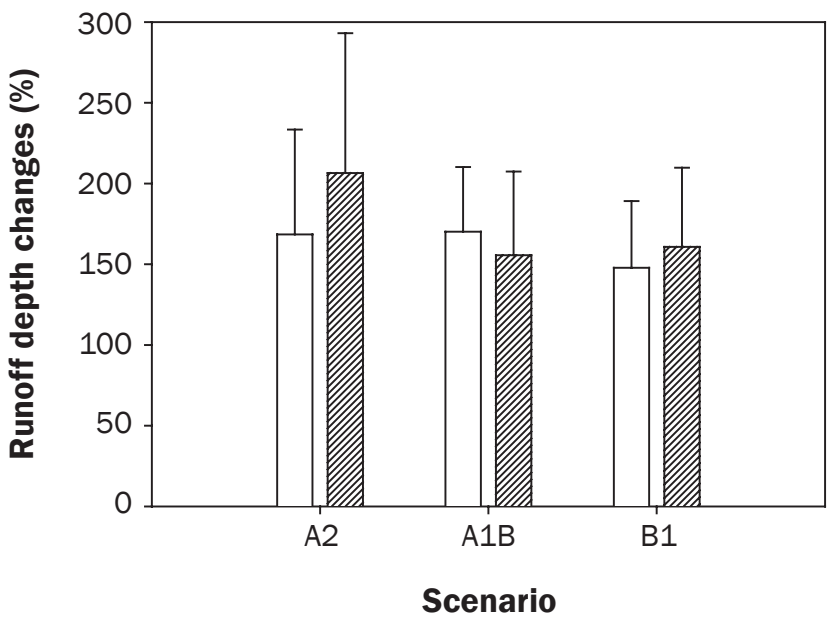

(d)

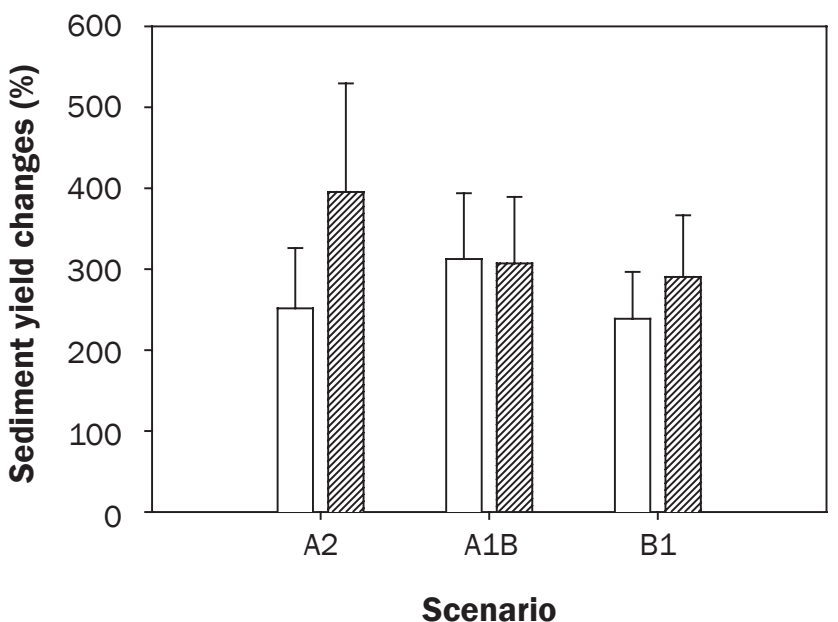

Legend

more pronounced than that in the summer, increasing by $148 \%$ to $201 \%$. Similarly, the trends of the projected seasonal changes in soil loss rates followed the same basic pattern as did the trends in seasonal runoff (figure 7). This increase in seasonal soil loss was more pronounced than that for seasonal runoff (figure 7). Predicted average soil loss rates in the summer and winter increased by $88 \%$ to $109 \%$ and $239 \%$ to $390 \%$, respectively, in the two future periods relative to 1970 to 1999 (figures $7 \mathrm{c}$ and $7 \mathrm{~d}$ ). However, it should be noted that soil erosion in this area is generally caused by high magnitude, low frequency rainfall events in the summer. Soil loss rates in the winter increase from $0.04 \mathrm{t} \mathrm{ha}^{-1}(0.02$ tn $\mathrm{ac}^{-1}$ ) during 1970 to 1999 to 0.15 to 0.18 $\mathrm{t} \mathrm{ha}^{-1}$ (0.07 to $0.08 \mathrm{tn} \mathrm{ac}^{-1}$ ) during the $2050 \mathrm{~s}$ and 2090s, which also fall within the range of measured values on rangelands in this area (Nearing et al. 2007; Polyakov et al. 2010b). Hence, the increases of soil erosion in the summer had more impact.The three emission scenarios predicted similar soil loss increases in the summer during the two future periods (figure 7c).
As for the distribution of annual runoff and soil loss across all the sample points, figure 8 shows the comparison of the histogram of annual runoff and soil loss averaged over the area between three future emission scenarios during 2030 to 2059 (projected) and historical observed rainfall during 1970 to 1999 The distribution of annual runoff and soil loss shifted to the right, which means more sample points with greater runoff and soil loss by the 2050s than those for the period 1970 to 1999. Similar trends were found for all the three emission scenarios during the 


\section{Figure 8}

Histograms of average annual (a, b, c, and d) runoff and (e, f, g, and h) soil loss for the three emission scenarios ( $A_{2}$ [b and f], A1B [c and g], and B1 [d and h]) for the time periods of 2030 to 2059 and for (a and e) the historical observed data during 1970 to 1999 across the 151 sample points.

(a)

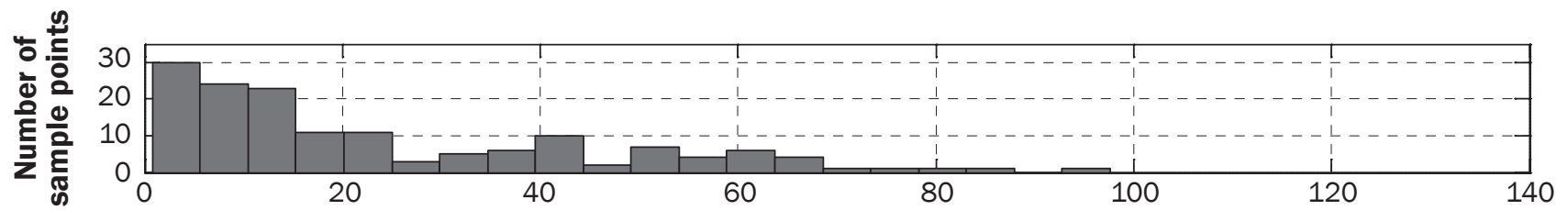

(b)

Annual runoff depth $(\mathrm{mm})$

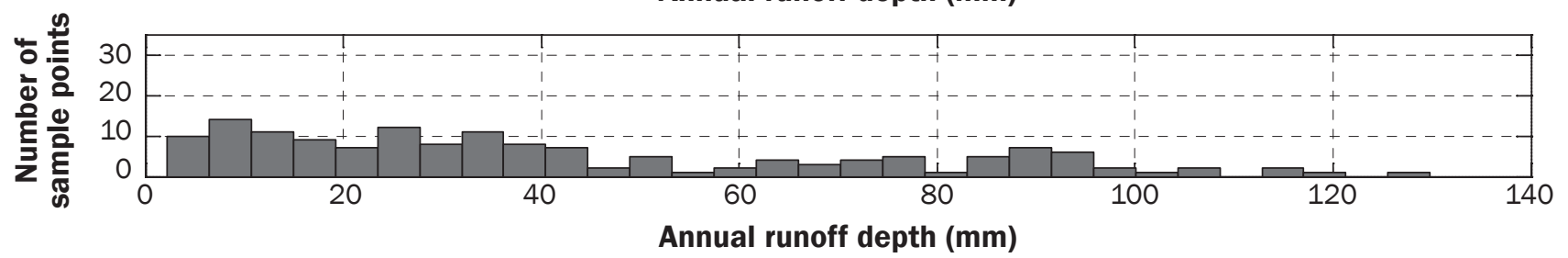

(c)

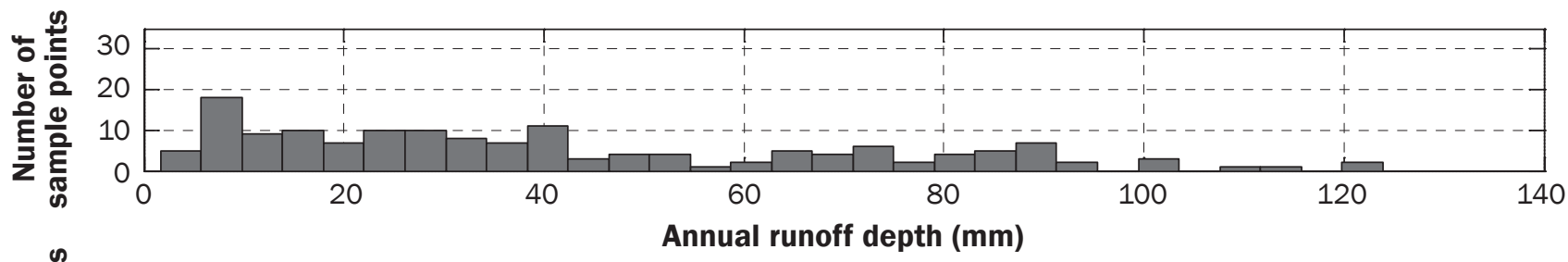

(d)

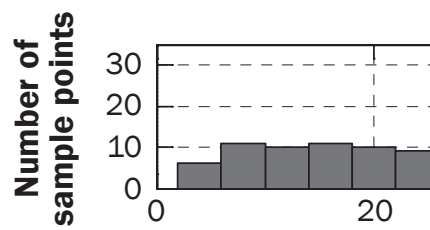

Annual runoff depth $(\mathrm{mm})$

(e)

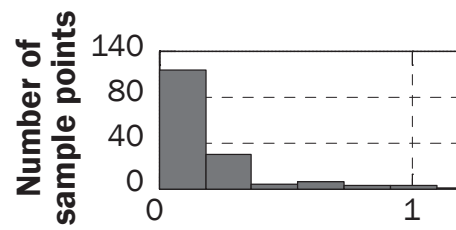

Annual runoff depth (mm)

(f)

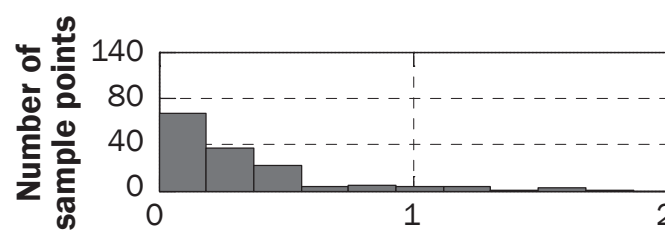

Annual soil loss (t ha-1)

(g)

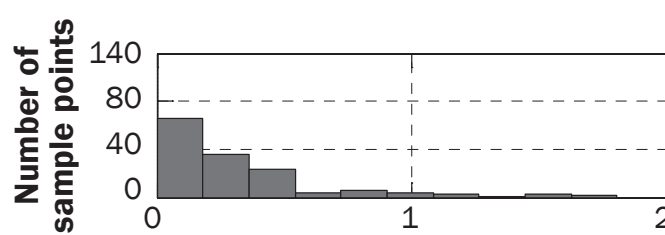

Annual soil loss ( $\left.\mathrm{t} \mathrm{ha}^{-1}\right)$

(h)

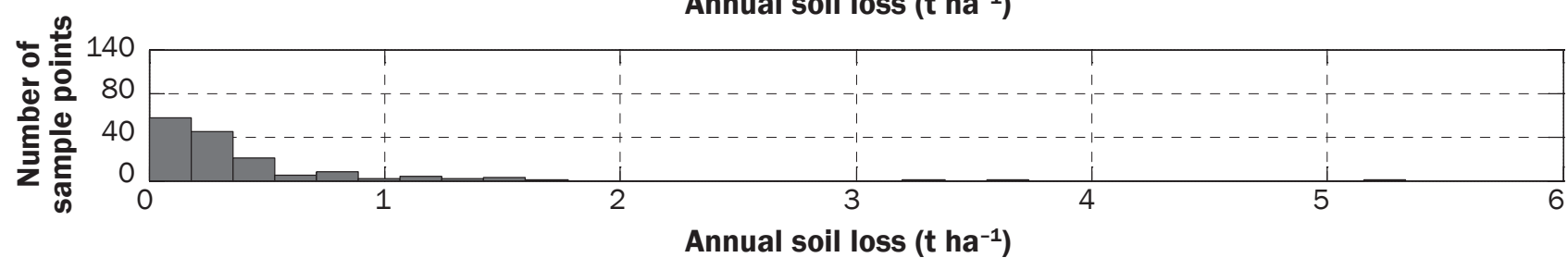


Table 7

Mean annual runoff and soil loss across the four plant communities (bunch grass [BUG], sod grass [SOG], annual grass and forbs [AGF], and shrub (SHR]) during two future and historical periods. Numbers in parentheses are the standard deviation of all sample points for each plant community.

2030 to 2059

\section{Annual}

runoff $(\mathbf{m m})$

BUG

SOG

AGF

SHR

Annual soil

loss (t ha-1)

\begin{tabular}{|c|c|c|c|c|c|c|c|}
\hline BUG & $0.13(0.15)$ & $0.25(0.23)$ & $0.24(0.22)$ & $0.24(0.22)$ & $0.26(0.23)$ & $0.24(0.22)$ & $0.23(0.21)$ \\
\hline SOG & $0.12(0.19)$ & $0.21(0.33)$ & $0.21(0.33)$ & $0.23(0.37)$ & $0.21(0.33)$ & $0.20(0.33)$ & $0.19(0.33)$ \\
\hline AGF & $0.29(0.75)$ & 0.50 (1.09) & 0.50 (1.05) & 0.50 (1.03) & $0.51(1.04)$ & 0.49 (1.03) & $0.47(1.02)$ \\
\hline SHR & $0.21(0.27)$ & $0.47(0.63)$ & 0.49 (0.69) & $0.48(0.63)$ & $0.51(0.76)$ & $0.48(0.69)$ & $0.45(0.65)$ \\
\hline
\end{tabular}

period of 2070 to 2099 (not shown). For annual runoff, there were 114 of 151 sample points with less than $40 \mathrm{~mm}$ (1.6 in) runoff during the period of 1970 through 1999 , while significant reductions of the number were found for the two future periods under all emission scenarios, ranging from 85 to 96 (Duncan tests, $\alpha=0.05$, table 4). During the period of 1970 through 1999, only two sample points had annual runoff greater than $80 \mathrm{~mm}$ (3.1 in), whereas 22 to 27 sample points have annual runoff greater than 80 $\mathrm{mm}$ by the middle and end of the present century under all three emission scenarios (table 4). There were no statistically significant changes in the number of sample points with annual runoff between 40 and $80 \mathrm{~mm}$ $(\alpha=0.05$, table 4$)$. Table 4 also shows similar trends of more sample points producing higher annual soil loss rates. There were fewer sample points with annual soil loss less than $0.50 \mathrm{t} \mathrm{ha}^{-1}\left(0.22 \mathrm{tn} \mathrm{ac}^{-1}\right)$ by the middle and end of present century relative to the period of 1970 through 1999, while significantly more sample points produced annual soil loss rates greater than $0.50 \mathrm{t} \mathrm{ha}^{-1}(\alpha=0.05$, figure $8 \mathrm{~b}$ and table 4$)$. These results indicated that much of the study area would experience more soil loss in the future.

Implications for Mitigation with Rangeland Conservation Practices. It is clear from the results of this study that in terms of the implications for rangeland conservation more concern should be targeted at the extreme events than ever before. Here we further analyzed the changes in runoff and soil loss across the four plant communities in MLRA 41 and then assessed management implications for each. The predicted mean annual runoff and soil loss averaged over each plant community are given in table 7 . Larger annual runoff volumes were produced on bunch grasses and sod grasses than that for shrubs and annual grasses and forbs for all the cases. In contrast, shrubs and annual grasses and forbs had greater soil loss rates than bunch grass and sod grass for all the cases. It is not surprising that both annual runoff and soil loss would significantly increase for the four plant communities under all the emission scenarios by the 2050s and 2090s as shown in figure 9. Of interest is the different response to precipitation change of the four plant communities, particularly with respect to soil loss. Mean annual soil loss increased more for shrub communities than for the other three plant communities under the three emission scenarios by the 2050s and 2070s relative to 1970 to 1999 , ranging from $112 \%$ to $140 \%$. This increase ranged from $61 \%$ to $75 \%$ for annual grasses and forbs under all the cases, from $71 \%$ to $91 \%$ for bunch grasses, and from 54\% to $87 \%$ for sod grasses (figure 9). These different changes under future climate change may be due to greater bare ground patch size and less basal cover as well as formation of rill on shrublands (Schlesinger et al. 1990, 1999), and hence, soil erosion is likely to be remarkably exacerbated.

Increasing soil erosion rates in the future, especially for shrubs and annual grasses and forbs, have implications for management practices in the context of climate and vegetation change in the southwestern United States. Shrub invasion has been occurring in the southwestern United States over the past century, and brushy or woody species in these communities have increased in density and cover (Cable and Martin 1973; McClaran
2003). Long-term increasing runoff and soil erosion may result in enough soil loss to accelerate the transition to degraded shrub states due to the positive vegetation-erosion feedback. Accelerating erosion on grasslands will cause increases in temporal and spatial heterogeneity for soil resources, especially with nutrients such as nitrogen (Schlesinger et al. 1990, 1999). These increases in the heterogeneity of soil resources could lead to the grassland degradation and shrub invasion, followed by redistribution of soil resources from plant interspaces to areas beneath shrub canopies (Okin et al.2009). Low soil nitrogen levels would favor establishment of species that have low soil nitrogen requirements, such as many leguminous shrubs (Johnson and Meyeux 1990). Furthermore, several studies have shown that in arid and semiarid ecosystems where soils are typically dry between events extreme precipitation events increased soil moisture at deeper layers that are less affected by evaporation (Sala et al. 1992; Knapp et al. 2008; Heisler-White et al. 2008; HeislerWhite et al.2009; Thomey et al.2010). Hence, in the context of no change or even decreased precipitation in the MLRA 41, the trends towards more extreme events would benefit soil moisture in the deep layer (Tietjen et al. 2010), which would also then favor growth of deep-rooted shrubs over grasses. According to state-and-transition models (Westoby et al. 1989), more soil erosion on shrublands in the future could mean significant shifts from shrubs to the eroded state, which implies that it is unlikely to be able to restore historical plant communities over time frames relevant to ecosystem management.

From a conservation standpoint, rangeland management practices are certain to 


\section{Figure 9}

Changes in mean annual runoff and soil loss across the four plant communities (bunch grass [BUG], sod grass [SOG], annual grass and forbs [AGF], and shrub [SHR]) under the three emission scenarios (A2, A1B, and B1) during the time periods of (a and c) 2030 to 2059 and (b and d) 2070 to 2099 relative to the period of 1970 to 1999 . Each value represents the mean of seven models ( \pm standard error).

(a)

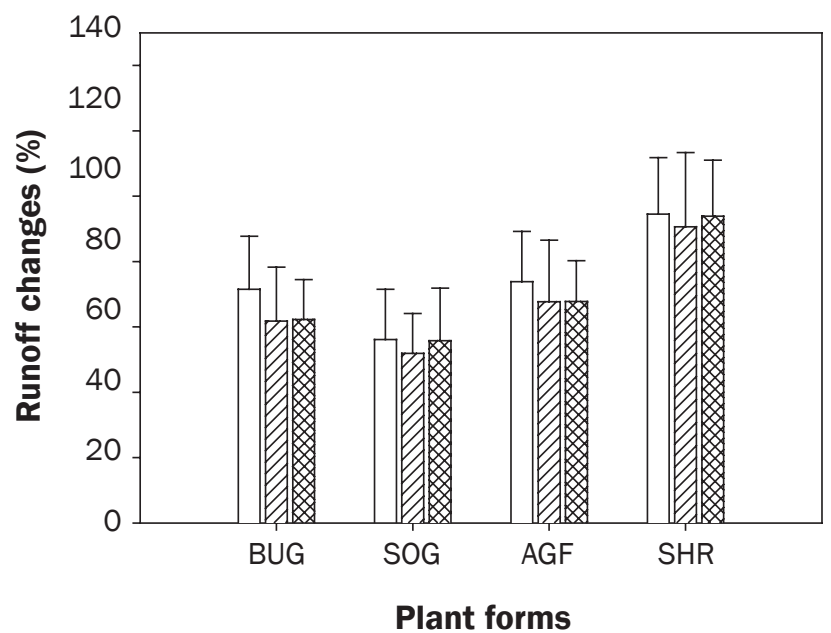

(c)

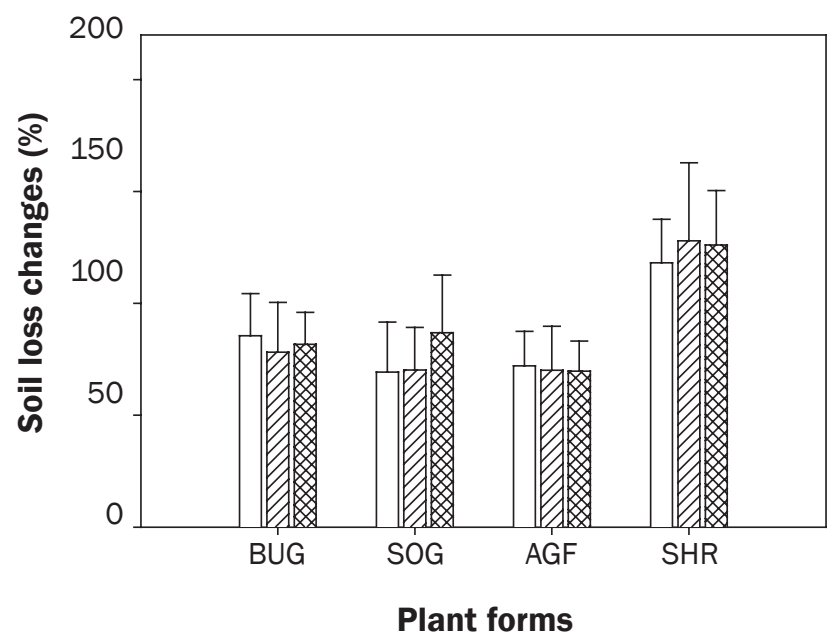

(b)

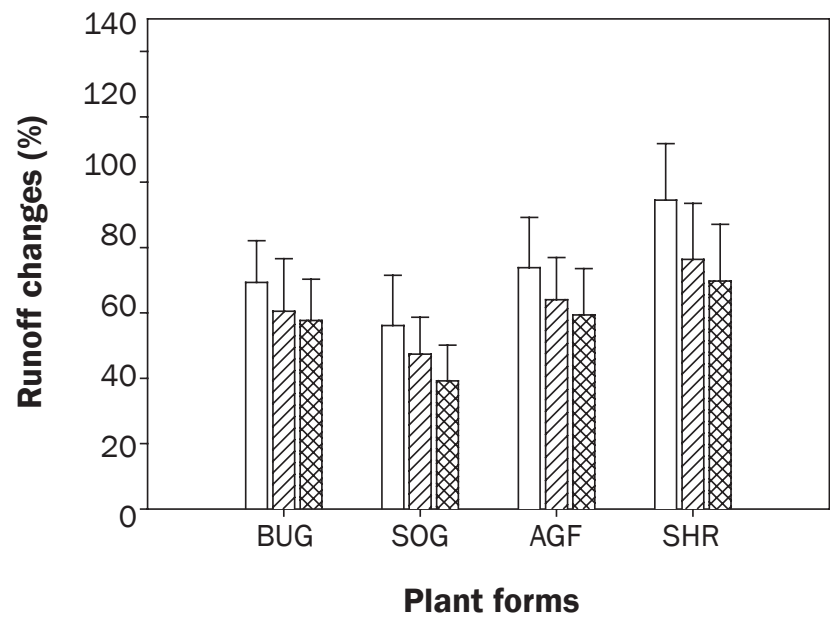

(d)

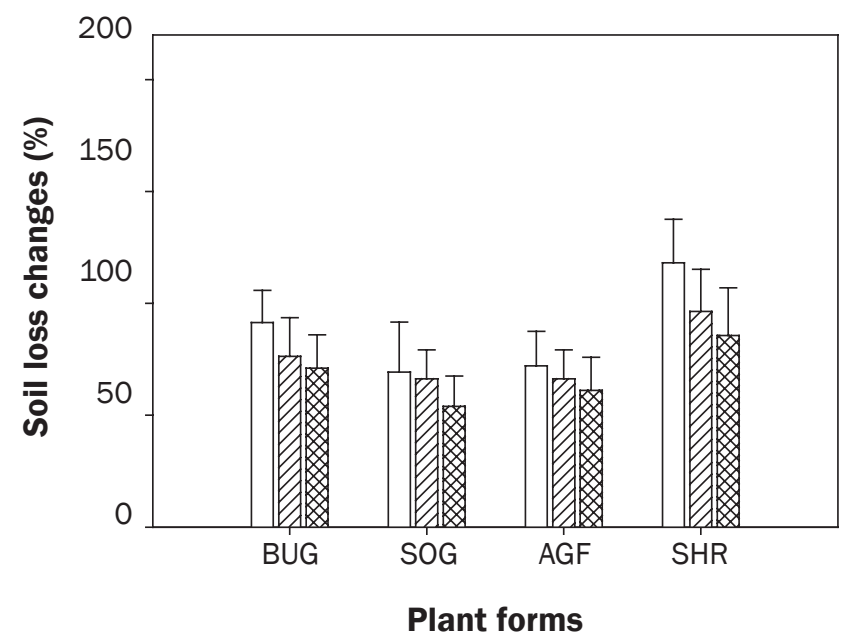

Legend

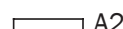

प्याय A1B

$\square \times B 1$

shift substantially where future precipitation changes result in significant alterations in runoff and soil erosion. As rangeland vegetation transitions toward more shrub-invaded or eroded states and as precipitation patterns change and extreme events happen more frequently, management practices need to incorporate the latest information on the impacts of changing precipitation regimes and increasing soil erosion. Adaption should include management practices that are less prone to erosion and increase the resiliency of rangelands to respond to climate change.
Livestock grazing management practices may need to change to match the new vegetation and climate. Livestock grazing is the most widespread management practice in the southwestern United States (Fleischner 1994). Coupled with warmer temperatures causing more frequent occurrence of droughts (Seager et al. 2007, 2010), the disturbances from increasing soil erosion in the future may be larger and more common than those experienced historically. Increasing soil erosion rates on grasslands might require a reduction of stocking rates or adjustment in the season of grazing. Grazing systems, such as rotation and seasonal suitability, might be used to alleviate the pressure of overgrazing on grasses. Periodic rest from grazing during the growing season is important for vegetation recovery and maintenance (Teague et al. 2004, 2010; Müller et al. 2007) and may help to reduce soil erosion. A reduction of precipitation and increase of runoff and soil loss in the winter (figures $4 \mathrm{~b}$ and 6) might negatively affect plant productivity on grasslands. As a result, stocking rates and grazing systems will need to be modified to optimize pasture use in the winter. 
Given the risk of greater accelerated soil erosion rates from shrublands than from grasslands in the coming decades in MLRA41, we suggest that currently uninvaded grasslands be made priorities for conservation management in order to reduce soil erosion. Management practices should be directed to keep a high grass cover and prevent the transition mechanisms that result in the degraded shrub-dominated state. In addition, land managers must consider the option of removing shrubs or at least controlling their expansion. Large rates of soil loss and greatly increased runoff rates from shrublands would lead to the degradation of soil physical and hydrological properties, including reduction in the soil A-horizon organic matter, compaction, and persistently reduced infiltration, which could hence limit the recruitment of perennial grasses. On sites where soil erosion dramatically changes the soil properties, the application of shrub treatments that effectively help to reestablish the grass cover should be implemented in early transition to a shrub-encroached state. In these cases, fire management and mechanical or herbicide treatment could be used to prevent the growth of shrubs. Many studies have found that less-costly prescribed fire, in combination with managed grazing and herbicide applications, can effectively reduce mesquite canopy cover and control invasive species for maintenance of local grasslands (Wright and Bailey 1982; Teague et al. 2010). In shrubinvaded grasslands of the southwestern United States, prescribed burning treatments have in some cases effectively eliminated mesquite and enhanced grass recovery by resulting in high shrub mortality and reducing competition for shallow soil moisture, eventually reducing erosion loss (Cable 1967; Martin 1983; DeBano et al. 1998; White and Loftin 2000; Parmenter 2008; Ravi and D'Odorico 2008). However, it is important to point out that present notions of best management practices might be inadequate for future planning because they draw heavily from our past knowledge. There is still considerable uncertainty concerning how these management practices are likely to be influenced under future climate in the context of more extreme climatic events and more common droughts in the southwestern United States.

Climate change is expected to affect runoff and soil erosion through multiple pathways, including changes in precipi- tation, temperature, atmospheric $\mathrm{CO}_{2}$ concentrations, and their interactions. Projected future changes in soil erosion rates in this study may be a conservative estimate because only the potential impacts of precipitation changes were evaluated We assumed here in the model projections that vegetation was unchanged in the future. The southwestern United States is expected to trend toward a warmer climate during the 21st century (Seager et al. 2007, 2010), which will very likely decrease the vegetation cover that protects the ground surface from soil erosion in semiarid rangelands (Ryan et al. 2008). Hence, future research needs to address the combined effects of warming, rising atmospheric $\mathrm{CO}_{2}$ concentrations, precipitation changes, and adaptations of rangeland management practices. Consideration of these factors will require much more extensive research.

\section{Summary and Conclusions}

The present study evaluated the potential impacts of precipitation changes on runoff and soil erosion in Major Land Resource Area 41 of southeastern Arizona rangelands for three future climate emission scenarios (A2, A1B, and B1) from seven GCMs using spatial-temporal downscaling techniques. The Rangeland Hydrology Erosion Model (RHEM) was used to simulate surface runoff and soil erosion for 151 sample points in MLRA41.

Our results suggested future runoff and soil erosion might increase significantly even if total annual or seasonal rainfall amounts were to remain unchanged or decrease. The results showed that mean annual precipitation would not significantly change or even slightly decrease throughout MLRA 41 under three emission scenarios for the periods of 2030 to 2059 and 2070 to 2099 relative to 1970 to 1999. In contrast, mean annual runoff and soil loss were predicted to dramatically increase for all the cases, from $79 \%$ to $92 \%$ and from $127 \%$ to $157 \%$, respectively.

Extreme events will play a key role in the increase of runoff and soil erosion in the future. In this study, the frequency and intensity of heavy events were projected to increase significantly, which then will result in dramatically accelerated soil erosion rates in the coming decades.

The likelihood of increases in heavy storms and soil erosion rates may accelerate the transition of grasslands to degraded shrub states due to the positive vegetation-erosion feedback (Schlesinger et al. 1990). Modeling results suggested that annual runoff and soil loss were projected to increase more for shrub communities than for other plant communities, with increases ranging from $112 \%$ to $140 \%$. Our study highlights the need to prevent further amplification of soil loss with effective rangeland management, such as prescribed fire, shrub treatments, and managed grazing. Increasing soil erosion on rangelands would have important ecological and environmental consequences and should be explicitly considered in the context of management. With more extreme events in the future, more concern about conservation management may be considered in respect to currently uninvaded grasslands.

Our study was limited in terms of the potential impacts of climate change because only changes of precipitation patterns were assessed. Future studies are needed to quantitatively assess the combined impacts of climate change, including changes in vegetation and mitigation with management practices. However, given the results in this study, coupled with warmer, drier climate and more heavy storms in the southwestern United States (Seager et al. 2007, 2010; Karl et al. 2009), the prospect is one of increased erosion rates under climate change for the foreseeable future.

\section{Acknowledgements}

This research was supported by the USDA Agricultural Research Service. We acknowledge the international modeling groups for providing their data for analysis and the Intergovernmental Panel on Climate Change Data Distribution Centre for collecting and archiving the model data. USDA is an equal opportunity provider and employer.

\section{References}

Baffaut, C., M.A. Nearing, and A.D. Nicks. 1996. Impact of CLIGEN parameters on WEPP-predicted average annual soil loss. Transaction of the American Society of Agricultural and Biological Engineers 39(2):447-457.

Cable, D.R. 1967. Fire effects on semidesert grasses and shrubs. Journal of Range Management 20:170-176.

Cable, D.R., and S.C. Martin. 1973. Invasion of semidesert grassland by velvet mesquite and associated vegetation changes. Arizona Academic Science 8:127-134.

DeBano, L.F., D.G. Neary, and P.F. Ffolliott. 1998. Fire's Effects on Ecosystems. New York: Wiley \& Sons.

Easterling, D.R., G.A. Meehl, C. Parmesan, S.A. Changnon, T.R. Karl, and L.O. Mearns. 2000. Climate extremes: Observations, modeling, and impacts. Science 289:2068-2074 
Ellis, A.W., G.B. Goodrich, and G.M. Garfin. 2010. A hydroclimatic index for examining patterns of drought in the Colorado River Basin. International Journal of Climatology 32(2):236-255.

Flanagan, D.C., and M.A. Nearing, eds. 1995. USDAWater Erosion Prediction Project: Hillslope Profile and Watershed Model Documentation. NSERL Report No.10.West Lafayette, IN: USDA Agricultural Research Service National Soil Erosion Research Lab.

Fleischner, T.L. 1994. Ecological costs of livestock grazing in western North America. Conservation Biology 8:629-644.

Goodrich, G., and A. Ellis. 2008. Climatic controls and hydrologic impacts of a recent extreme seasonal precipitation reversal in Arizona. Journal of Applied Meteorology and Climatology 47(2):498-508.

Groisman, P.Y., R.W. Knight, T.R. Karl, D.R. Easterling, B. Sun, and J.H. Lawrimore. 2004. Contemporary changes of the hydrological cycle over the contiguous United States: Trends derived from in situ observations. Journal of Hydrometeorology 5:64-85.

Heisler-White, J.L., J.M. Blair, E.F. Kelly, K. Harmoney, and A.K. Knapp. 2009. Contingent productivity responses to more extreme rainfall regimes across a grassland biome. Global Change Biology 15(12):2894-2904.

Heisler-White, J.L., A.K. Knapp, and E.F. Kelly. 2008. Increasing precipitation event size increases aboveground net primary productivity in a semi-arid grassland. Oecologia 158:129-140.

IPCC (Intergovernmental Panel on Climate Change) 2007. Climate Change 2007. The Physical Science Basis. Contribution of Working Group I to the Fourth Assessment Report of the Intergovernmental Panel on Climate Change, ed. S. Solomon et al. Cambridge, UK: Cambridge University Press.

Johnson, H.B., and H.S. Meyeux,Jr. 1990. Prosopis glandulosa and the nitrogen balance of rangeland: Extent and occurrence of nodulation. Oecologia 84:176-85.

Karl, T.R., and R.W. Knight. 1998. Secular trends of precipitation amount, frequency, and intensity in the United States. Bulletin of the American Meteorological Society 79(2):231-241.

Karl, T.R., J.M. Melillo, and T.C. Peterson. 2009. Global Climate Change Impacts in the United States. Cambridge: Cambridge University Press.

Knapp, A.K., C. Beier, D.D. Briske, A.T. Classen, Y. Luo, M. Reichstein, M.D. Smith, S.D. Smith, J.E. Bell, P.A. Fay, J.L. Heisler, S.W. Leavitt, R. Sherry, B. Smith, and E. Weng. 2008. Consequences of more extreme precipitation regimes for terrestrial ecosystems. BioScience 58:811-821.

Martin, S.C. 1983. Response of semidesert grasses and shrubs to fall burning. Journal of Range Management 36:604-610.

Martin, S.C., and H.L. Morton. 1993. Mesquite control increases grass density and reduces soil loss in southern Arizona. Journal of Range Management 46:170-175.
McClaran, M.P. 2003. A century of vegetation change on the Santa Rita Experimental Range. In Santa Rita Experimental Range: 100 years (1903-2003) of accomplishments and contributions., eds. M.P.McClaran, P.F. Ffolliott, C.B. Edminster, 16-33. RMRS-P-30. Ogden, UT: USDA, Forest Service, Rocky Mountain Research Station.

Müller, B., K. Frank, and D.C. Wissel. 2007. Relevance of rest periods in nonequilibrium rangeland systems: A modeling analysis. Agricultural Systems 92:295-317.

Murphy, J.M. 1999. An evaluation of statistical and dynamical techniques for downscaling local climate. Journal of Climate 12:2256-2284.

Nearing, M.A., V. Jetten, C. Baffaut, O. Cerdan, A. Couturier, M.Hernandez,Y.Le Bissonnais, M.H.Nichols,J.P. Nunes, C.S. Renschler, V. Souchere, and K. van Oost. 2005. Modeling response of soil erosion and runoff to changes in precipitation and cover. Catena 61(2-3):131-154.

Nearing, M.A., M.H. Nichols, K.G. Renard, and J.R. Simanton. 2007. Sediment yields from unit-source semi-arid watersheds at Walnut Gulch. Water Resources Research 43, W06426, doi:10.1029/2006WR005692.

Nearing, M.A., H. Wei, J.J. Stone, F.B. Pierson, K.E. Spaeth, M.A. Weltz, D.C. Flanagan, and M. Hernandez. 2011. A rangeland hydrology and erosion model. Transactions of the American Society of Agricultural and Biological Engineers 54(3):901-908.

Nicks, A.D., and G.A. Gander. 1994. CLIGEN: A weather generator for climate inputs to water resource and other models. In Proceeings of the 5th International Conference on Computers in Agriculture, 3-94. St. Joseph, MI: American Society of Agricultural Engineers.

Okin, G.S., P. D'Odorico, and S.R. Archer. 2009. Impact of feedbacks on Chihuahuan desert grasslands: Transience and metastability. Journal of Geophysical Research, doi: 10.1029/2008JG000833.

O'Neal, M.R., M.A. Nearing, R.C. Vining, J. Southworth, and R.A. Pfeifer. 2005. Climate change impacts on soil erosion in Midwest United States with changes in crop management. Catena 61:165-184.

Parmenter, R.R. 2008. Long-Term effects of a summer fire on desert grassland plant demographics in New Mexico. Rangeland Ecological Management 61:156-16.

Platt, K.B. 1959. Plant control-Some possibilities and limitations I: The challenge to management. Journal of Range Manage 12:64-68.

Polyakov, V., M.A. Nearing, M.H. Nichols, R.L. Scott, J.J. Stone, and M. McClaran. 2010a. Runoff and sediment yields from small semi-arid watersheds in southern Arizona. Water Resources Research 46:1-12.

Polyakov,V., M.A. Nearing, J.J. Stone, E.P. Hamerlynck, M.H. Nichols, C. Holifield Collins, and R.L. Scott. 2010 b. Runoff and erosional response to a drought-induced shift in a desert grassland community composition. Journal of Geophysical Research 115, G04027.

Pruski, F.F., and M.A. Nearing. 2002. Climate-induced changes in erosion during the 21 st century for eight
US locations. Water Resources Research 38(12):1298, doi:10.1029/2001WR000493.

Ravi, S., and P. D'Odorico. 2008. Post-fire resource redistribution and fertility island dynamics in shrub encroached desert grasslands: A modeling approach. Landscape Ecology, doi:10.1007/s10980-008-9307-7.

Ritchie, J.C., M.A. Nearing, and F.E. Rhoton. 2009. Sediment budgets and source determinations using fallout Cesium-137 in a semiarid rangeland watershed, Arizona, USA. Journal of Environmental Radioactivity 100:637-643.

Ryan, M.G., S.R. Archer, R. Birdsey, C. Dahm, L. Heath, J. Hicke, D. Hollinger, T. Huxman, G. Okin, R. Oren, J. Randerson, and W. Schlesinger. 2008. Land Resources. In The effects of climate change on agriculture, land resources, water resources, and biodiversity in the United States. Washington, DC: USDA.

Sala, O.E., W.K. Lauenroth, W.J.Parton. 1992. Long-term soil water dynamics in the shortgrass steppe. Ecology 73(4):1175-1181.

SAS Institute Inc. 2003. SAS® 9.1 User's Guide. Cary, NC: SAS Institute Inc.

Schlesinger, W.H., A.D. Abrahams, A.J. Parsons, and J.Wainwright. 1999. Nutrient losses in runoff from grassland and shrubland habitats in southern New Mexico: Rainfall simulation experiments. Biogeochemistry 45:21-34.

Schlesinger, W.H., J.F. Reynolds, G.L. Cunningham, L.F. Huenneke, and W.M. Jarrell. 1990. Biological feedbacks in global desertification. Science 247:1043-48.

Seager, R., M.F. Ting, I.M. Held, Y. Kushnir, J. Lu, G.Vecchi, H-P. Huang, N. Harnik, A. Leetmaa, N-C. Lau, C. Li, J. Velez, and N. Naik .2007. Model projections of an imminent transition to a more arid climate in Southwestern North America. Science 316:1181-1184.

Seager, R., and G.A.Vecchi. 2010. Greenhouse warming and the 21st century hydroclimate of southwestern North America. Proceedings of the National Academy of Sciences 107:21277-21282.

Teague, W.R., S.L. Dowhower, R.J. Ansley, W.E. Pinchak, and J.A. Waggoner. 2010. Integrated grazing and prescribed fire restoration strategies in a mesquite savanna: I.Vegetation responses. Rangeland Ecology and Management 63:275-285.

Teague, W.R., S.L. Dowhower, and J.A. Waggoner. 2004. Drought and grazingpatch dynamics under different grazing management. Journal of Arid Environments 58:97-117.

Thomey, M.L., S.L. Collins, R. Vargas, J.E. Johnson, R.F. Brown, D.O. Natvig, M.T. Friggens. 2011. Effect of precipitation variability on net primary production and soil respiration in a Chihuahuan Desert grassland. Global Change Biology 17:1505-1515.

Tietjen, B., F. Jeltsch, E. Zehe, N. Classen, A. Groengroeft, K. Schiffers, and J. Oldeland. 2010. Effects of climate change on the coupled dynamics of water and vegetation in drylands. Ecohydrology 3:226-237. 
USDA NRCS (Natural Resources Conservation Service). 2006. Land Resource Regions and Major Land Resource Areas of the United States, the Caribbean, and the Pacific Basin. USDA Handbook 296. Washington, DC: USDA Natural Resources Conservation Service.

USDA NRCS. 2012. Soil Survey Geographic (SSURGO) Database for Arizona. http://soildatamart.nrcs.usda.gov.

Wei, H., M.A. Nearing, J.J. Stone, D.P. Guertin, K.W. Spaeth, F. Pierson, M.H. Nichols, and C.A. Moffett. 2009. A new splash and sheet erosion equation for rangelands. Soil Science Society of America Journal 73:1386-1392.

Weltz, M.A., L. Jolley, M.A. Nearing, J.J. Stone, D.C. Goodrich, F. Pierson, Jr, K. Speath, J. Kiniry, J. Arnold, D. Bubenheim, M. Hernandez, and H. Wei. 2008. Assessing the benefits of grazing land conservation practices. Journal of Soil and Water Conservation 63(6):214-217, doi:10.2489/jswc.63.6.214A.

Westoby, M., B.Walker, and I. Noy-Meir. 1989. Opportunistic management for rangelands not at equilibrium. Journal of Range Management 42:266-274.

White, C.S., and S.R. Loftin. 2000. Response of 2 semiarid grasslands to cool season prescribed fire. Journal of Range Management 53:52-61.

Wilks, D.S. 1999. Multisite downscaling of daily precipitation with a stochastic weather generator. Climate Research 11:125-136.

Wright, H.A., and A.W. Bailey. 1982. Fire Ecology. New York: John Wiley \& Sons.

Zhang,Y.G., M.A. Nearing , B.Y. Liu, R.S.Van Pelt, J.J. Stone, H.Wei, and R.L. Scott. 2011. Comparative rates of wind versus water erosion from a small semiarid watershed in southern Arizona, USA. Aeolian Research 3:197-204.

Zhang,Y.G., M.A. Nearing, X.C. Zhang, Y. Xie, and H. Wei. 2010. Projected rainfall erosivity changes under climate change from multimodel and multiscenario projections in Northeast China. Journal of Hydrology 384:97-106.

Zhang, X.C. 2005. Spatial downscaling of global climate model output for site-specific assessment of crop production and soil erosion. Agricultural and Forest Meteorology 135:215-229.

Zhang, X.C. 2007. A comparison of explicit and implicit spatial downscaling of GCM output for soil erosion and crop production assessments. Climate Change 84:337-363.

Zhang, X.C., and W.Z. Liu. 2005. Simulating potential response of hydrology, soil erosion, and crop productivity to climate change in Changwu tableland region on the Loess Plateau of China. Agricultural and Forest Meteorology 131:127-142.

Zhang, X.C., M.A. Nearing, J.D. Garbrecht, and J.L. Steiner. 2004. Downscaling monthly forecasts to simulate impacts of climate change on soil erosion and wheat production. Soil Science Society of America Journal 68:1376-1385. 